NBER WORKING PAPER SERIES

CREDIT SUPPLY AND THE HOUSING BOOM

\author{
Alejandro Justiniano \\ Giorgio E. Primiceri \\ Andrea Tambalotti \\ Working Paper 20874 \\ http://www.nber.org/papers/w20874
NATIONAL BUREAU OF ECONOMIC RESEARCH
1050 Massachusetts Avenue
Cambridge, MA 02138
January 2015

We thank Tobias Adrian, Larry Christiano, Simon Gilchrist, Cosmin Ilut, Igor Livshits, Ander Perez, Monika Piazzesi, Vincenzo Quadrini, Giacomo Rondina, Martin Schneider, Amir Sufi as well as seminar and conference participants for comments and suggestions. Giorgio Primiceri thanks Bocconi University and EIEF for their hospitality while conducting part of this research. The views expressed in this paper are those of the authors and do not necessarily represent those of the Federal Reserve Banks of Chicago, New York or the Federal Reserve System. Giorgio Primiceri is a consultant for the Federal Reserve Bank of Chicago and a research visitor at the European Central Bank. The views expressed herein are those of the authors and do not necessarily reflect the views of the National Bureau of Economic Research.

NBER working papers are circulated for discussion and comment purposes. They have not been peerreviewed or been subject to the review by the NBER Board of Directors that accompanies official NBER publications.

(C) 2015 by Alejandro Justiniano, Giorgio E. Primiceri, and Andrea Tambalotti. All rights reserved. Short sections of text, not to exceed two paragraphs, may be quoted without explicit permission provided that full credit, including (C) notice, is given to the source. 
Credit Supply and the Housing Boom

Alejandro Justiniano, Giorgio E. Primiceri, and Andrea Tambalotti

NBER Working Paper No. 20874

January 2015

JEL No. E32,E44

\begin{abstract}
$\underline{\text { ABSTRACT }}$
The housing boom that preceded the Great Recession was due to an increase in credit supply driven by looser lending constraints in the mortgage market. This view on the fundamental drivers of the boom is consistent with four empirical observations: the unprecedented rise in home prices and household debt, the stability of debt relative to house values, and the fall in mortgage rates. These facts are difficult to reconcile with the popular view that attributes the housing boom to looser borrowing constraints associated with lower collateral requirements. In fact, a slackening of collateral constraints at the peak of the lending cycle triggers a fall in home prices in our framework, providing a novel perspective on the possible origins of the bust.
\end{abstract}

\author{
Alejandro Justiniano \\ Economic Research Department \\ Federal Reserve Bank of Chicago \\ 230 S. LaSalle Street \\ Chicago, IL 60604 \\ ajustiniano@frbchi.org \\ Giorgio E. Primiceri \\ Department of Economics \\ Northwestern University \\ 318 Andersen Hall \\ 2001 Sheridan Road \\ Evanston, IL 60208-2600 \\ and NBER \\ g-primiceri@northwestern.edu
}

\author{
Andrea Tambalotti \\ Federal Reserve Bank of New York \\ Research and Statistics Group \\ 33 Liberty Street, 3rd Floor \\ New York, NY 10045 \\ a.tambalotti@gmail.com
}




\title{
CREDIT SUPPLY AND THE HOUSING BOOM
}

\author{
ALEJANDRO JUSTINIANO, GIORGIO E. PRIMICERI, AND ANDREA TAMBALOTTI
}

\begin{abstract}
The housing boom that preceded the Great Recession was due to an increase in credit supply driven by looser lending constraints in the mortgage market. This view on the fundamental drivers of the boom is consistent with four empirical observations: the unprecedented rise in home prices and household debt, the stability of debt relative to house values, and the fall in mortgage rates. These facts are difficult to reconcile with the popular view that attributes the housing boom to looser borrowing constraints associated with lower collateral requirements. In fact, a slackening of collateral constraints at the peak of the lending cycle triggers a fall in home prices in our framework, providing a novel perspective on the possible origins of the bust.
\end{abstract}

\section{INTRODUCTION}

The U.S. economy recently experienced a severe financial crisis that precipitated the worst recession since the Great Depression. Housing and mortgage markets were at the center of these events. Four facts characterize the behavior of these markets in the period leading up to the collapse in house prices and the ensuing financial turmoil.

FACT 1: House prices rose dramatically. Between 2000 and 2006 real home prices increased roughly between 40 and 70 percent, depending on measurement, as shown in Figure 1.1. This unprecedented boom was followed by an equally spectacular bust after 2006 .

FACT 2: Households' mortgage debt surged. This is illustrated in figure 1 for both the aggregate household sector and for financially constrained households in the Survey of Consumer Finances (SCF) - the group that is most informative for the parametrization of our model. Both measures of indebtedness were stable in the 1990s, but increased by about

Date: First version: March 2014. This version: January 2015.

We thank Tobias Adrian, Larry Christiano, Simon Gilchrist, Cosmin Ilut, Igor Livshits, Ander Perez, Monika Piazzesi, Vincenzo Quadrini, Giacomo Rondina, Martin Schneider, Amir Sufi as well as seminar and conference participants for comments and suggestions. Giorgio Primiceri thanks Bocconi University and EIEF for their hospitality while conducting part of this research. The views expressed in this paper are those of the authors and do not necessarily represent those of the Federal Reserve Banks of Chicago, New York or the Federal Reserve System. 


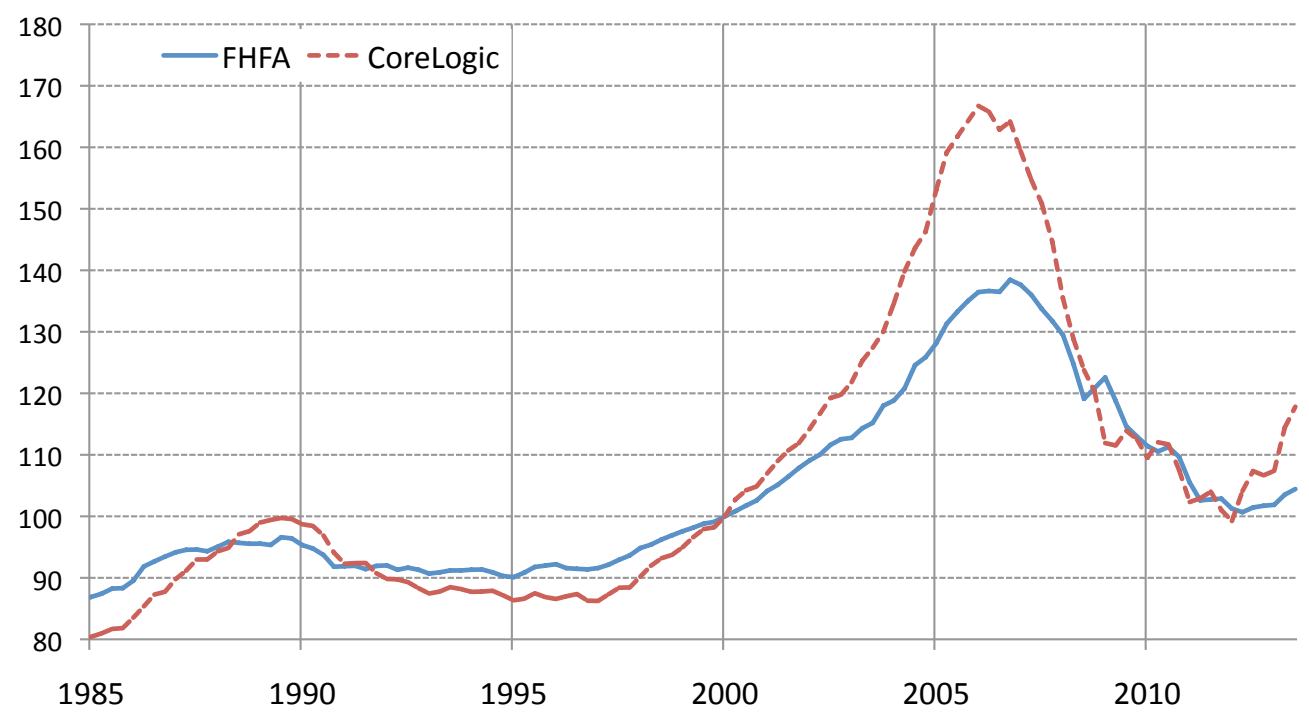

FIGURE 1.1. Real house prices. FHFA (formerly OFHEO) all-transactions house price index for the United States and CoreLogic Home Price Index (HPI). Both indexes are deflated by the consumer price index, and normalized to 100 in 2000:Q1.

30 and 60 percentage points between 2000 and 2007, before falling during the financial crisis.

FACT 3: Mortgage debt and house prices increased in parallel. As a result, the ratio of home mortgages to the value of residential real estate remained roughly unchanged into 2006. This often under-appreciated fact is documented in figure 1.3, which also shows that this aggregate measure of household leverage spiked when home values collapsed before the recession.

FACT 4: Real mortgage rates declined. Figure 1.4 plots the 30-year conventional mortgage rate minus various measures of inflation expectations from the Survey of Professional Forecasters. It shows that real mortgage rates fluctuated around 5\% during the 1990s, but fell by 2 to 3 percentage points as the housing boom unfolded.

We argue that the key factor behind these four phenomena was a progressive relaxation of lending constraints starting in the late 1990s, which led to a significant expansion in the supply of mortgage credit. This account of the facts is in contrast with the more conventional view that attributes the boom to looser borrowing limits.

To highlight this contrast, we develop a simple general equilibrium framework that draws a particularly stark distinction between the supply and demand for credit. On the demand 
(a): Mortgages-to-GDP ratio (Flow of Funds)

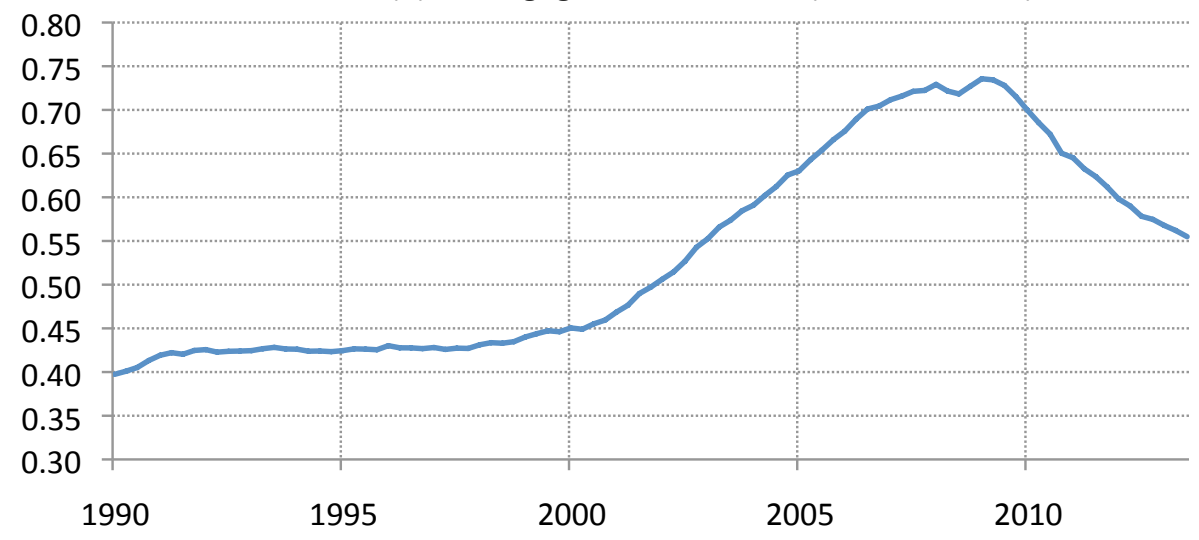

(b): Mortgages-to-income ratio (SCF)

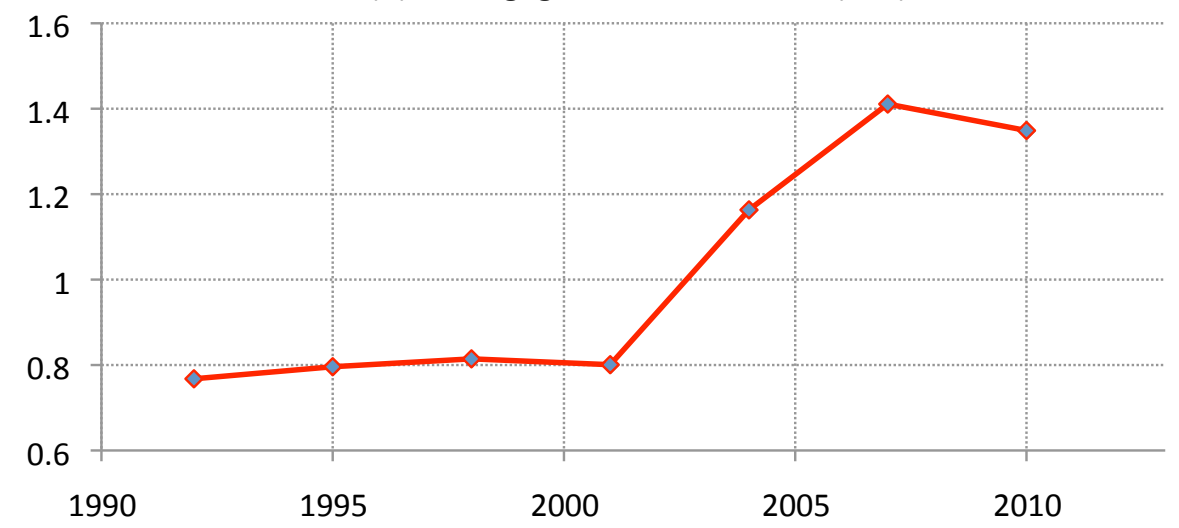

FiguRE 1.2. (a): Mortgages-to-GDP ratio (Flow of Funds). Mortgages are home mortgages from the balance sheet of households and nonprofit organizations in the Flow of Funds. (b): Mortgages-to-income ratio (SCF). Ratio of mortgage debt to income for the households with little liquid financial assets in the Survey of Consumer Finances, as defined in section 4.1.

side, a collateral constraint limits households' ability to borrow against the value of real estate, as in the large literature spawned by Kiyotaki and Moore (1997). On the credit supply side, a lending constraint impedes the flow of savings to the mortgage market. A slackening of this constraint increases the funding available to borrowers, leading to lower mortgage rates and higher house prices, with no change in aggregate household leverage, as in the four facts. On the contrary, an increase in the maximum loan-to-value (LTV) ratio - or equivalently a fall in required down payments - slackens the borrowing constraint 
(a): Mortgages-to-real estate ratio (Flow of Funds)

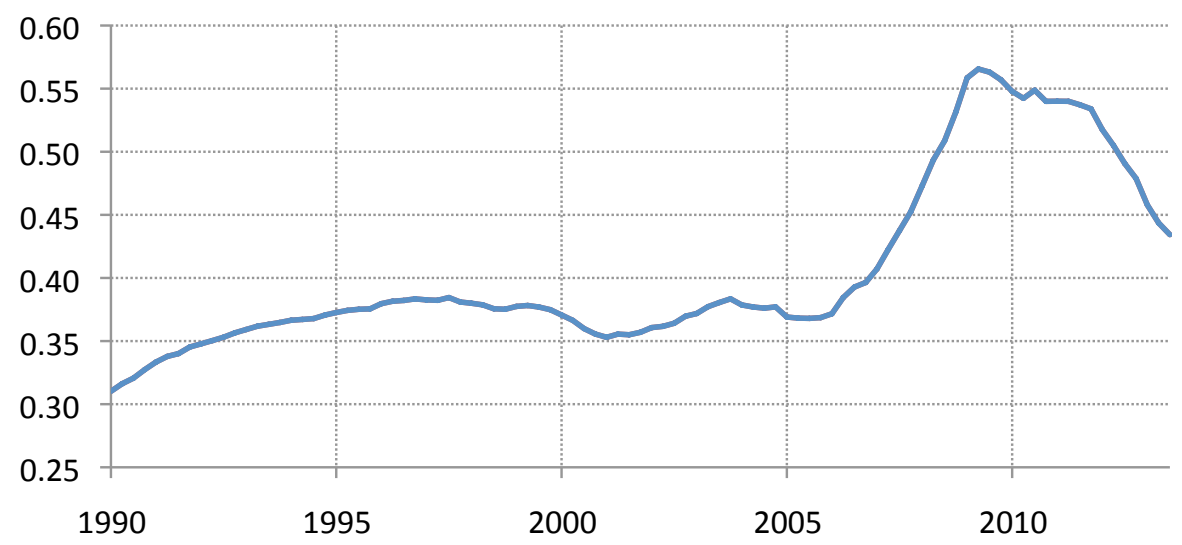

(b): Mortgages-to-real estate ratio (SCF)

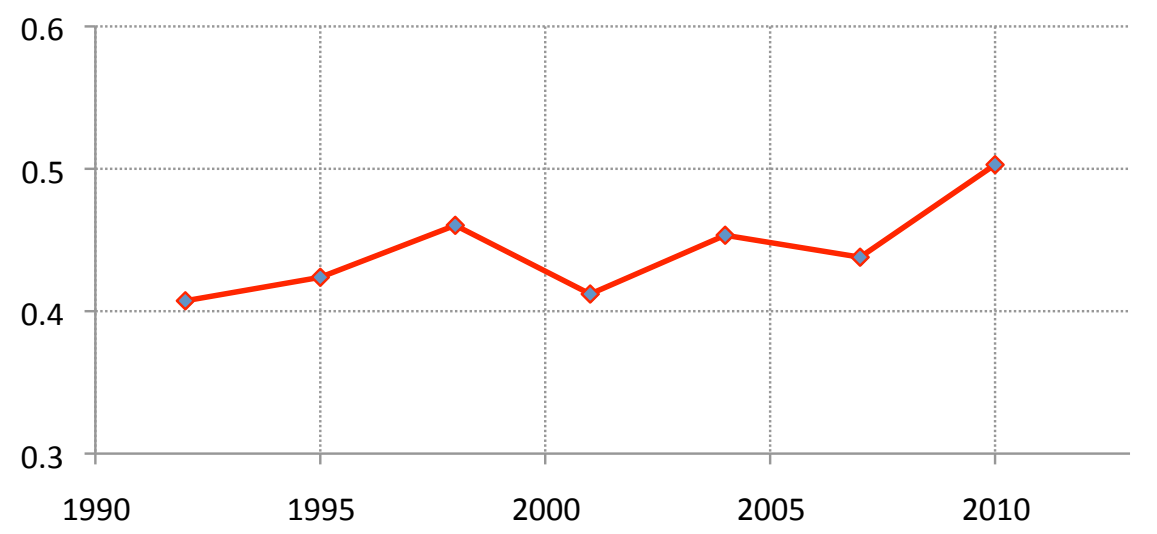

Figure 1.3. (a): Mortgages-to-real estate ratio (Flow of Funds). Mortgages are defined as in figure 1. Real estate is the market value of real estate from the balance sheet of households and nonprofit organizations in the Flow of Funds. (b): Mortgages-to-real estate ratio (SCF). Ratio of mortgage debt to the value of real estate for the households with little financial assets in the Survey of Consumer Finances, as defined in section 4.1.

and increases credit demand for given house prices, putting upward pressure on interest rates and leading to higher aggregate leverage.

Lending constraints are the main novel feature of our framework. They are a simple modeling device to capture a combination of technological, institutional, and behavioral factors that restrain the flow of funds from savers to mortgage borrowers. ${ }^{1}$ Starting in the

${ }^{1}$ For simplicity, we impose the lending constraint directly on savers, but we show that a leverage restrictionor, equivalently, a capital requirement-imposed on financial intermediaries would produce identical results. 


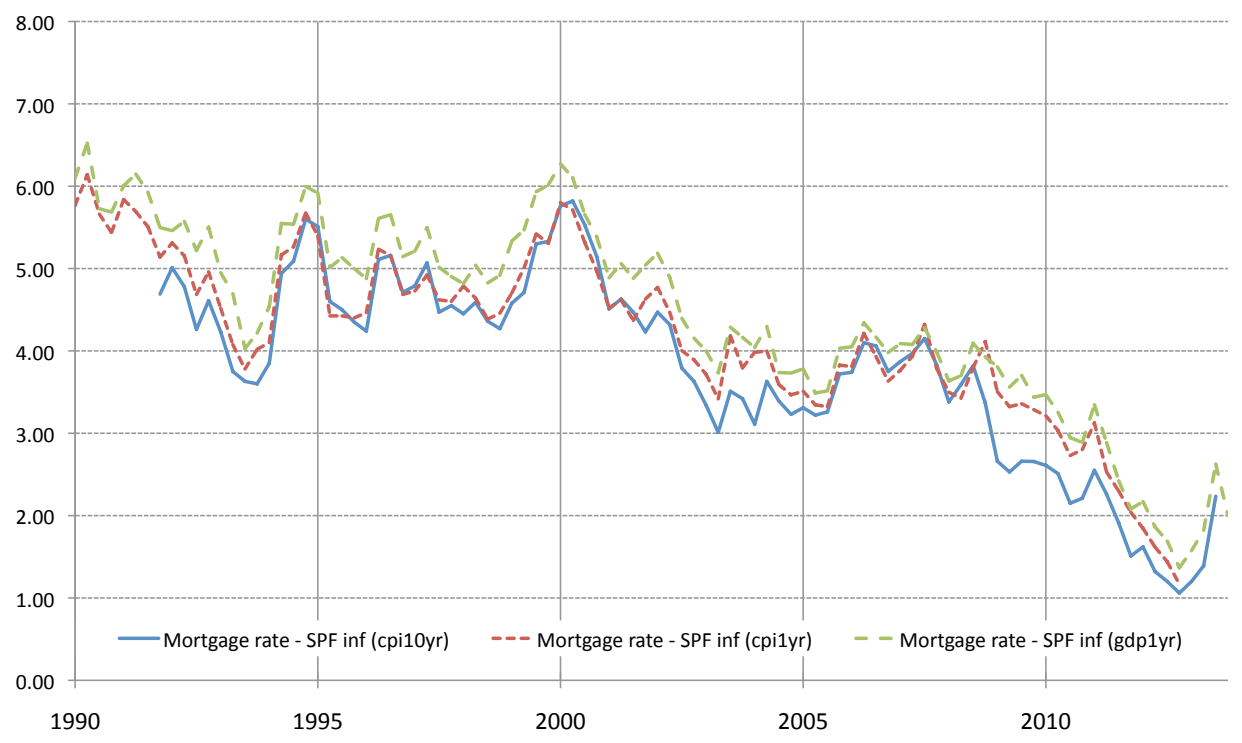

FIGURE 1.4. Real mortgage interest rates. 30-year conventional mortgage rate minus three measures of expected inflation from the Survey of Professional Forecasters: 10-year-ahead CPI inflation forecast (blue solid), 1-year-ahead CPI inflation forecast (red dashed), and 1-year-ahead GDP deflator forecast (green long dash).

late 1990s, the explosion of securitization and of market-based financial intermediation, together with changes in the regulatory and economic environment, lowered many of these barriers. We model this reduction in the frictions impeding the free flow of savings into mortgage finance as a relaxation of lending constraints. Among the sources of looser lending constraints, the pooling and tranching of mortgages into mortgage-backed securities (MBS) plays a central role, through several channels. ${ }^{2}$ First, tranching creates highly rated assets out of pools of risky mortgages. These assets can then be purchased by those institutional investors that are restricted by regulation to only hold fixed-income securities with high ratings. As a result, the boom in securitization contributed to channel into mortgages a large pool of savings that had previously been directed towards other safe assets, such as government bonds (Brunnermeier, 2009). Second, investing in those same senior MBS tranches freed up intermediary capital, due to their lower regulatory charges. Combined

\footnotetext{
${ }^{2}$ Securitization started in the late 1960s, when the Government Sponsored Enterprises created the first mortgage-backed securities (e.g. Gerardi et al., 2010, Fostel and Geanakoplos, 2012). However, it did not take off until the late 1990s and early 2000s, with the development of increasingly sophisticated structures that enabled the expansion of private-label MBS beyond conforming mortgages and ultimately into subprime products (Levitin and Wachter, 2012).
} 
with the rise of off-balance-sheet vehicles, this form of "regulatory arbitrage" allowed banks to increase leverage without raising new capital, expanding their ability to supply credit to mortgage markets (Acharya and Richardson, 2009, Acharya et al., 2013, Nadauld and Sherlund, 2009). Third, securitization allowed banks to convert illiquid loans into liquid funds, reducing their funding costs and hence increasing their capacity to lend (Loutskina and Strahan 2009, Loutskina, 2011).

More in general, the "Great Moderation" in macroeconomic volatility, together with the backdrop of ever rising house prices, led financial intermediaries to an (ex-post) overoptimistic assessment of the risks faced by their portfolios. This overoptimism loosened the leverage constraints dictated by their internal risk management practices, often based on Value at Risk (VaR) models, generating higher leverage and more lending (e.g. Adrian and Shin, 2014).

International factors also played an important role in increasing the supply of funds to U.S. mortgage borrowers. Following the Asian crisis in the late 1990s, a "glut" of global savings flowed towards U.S. safe assets, finding its way into the mortgage market through the purchase of MBS, as documented by Bernanke et al. (2011). In our simple model, this inflow of foreign funds into mortgage products can be modeled as a slackening of the lending constraint, which shifts the overall amount of funds available to borrowers. ${ }^{3}$

We use our model to analyze the effects of this relaxation of lending constraints on the macroeconomy, both qualitatively and quantitatively. For the quantitative part of the analysis, we calibrate the model to match some key properties of the balance sheet of the U.S. household sector in the 1990s using the Survey of Consumer Finances.

An important assumption underlying this exercise is that the US economy in the 1990s was constrained by a limited supply of funds to the mortgage market, rather than by a scarcity of housing collateral. Starting from this situation, we show that a progressive loosening of the lending constraint in the residential mortgage market increases household debt in equilibrium (fact 2). If the resulting shift in the supply of funds is large enough, the availability of collateral also becomes a binding constraint. Then, a further expansion of the lending limit boosts the collateral value of houses, increasing their price (fact 1), while the interest rate falls (fact 4). Moreover, higher real estate values endogenously

\footnotetext{
${ }^{3}$ Justiniano et al., 2014b provide a quantitative analysis of the impact of the saving glut on the housing and
} credit boom in the U.S. 
relax the borrowing constraint, leading to an increase in household debt at an unchanged debt-to-collateral ratio (fact 3).

In contrast, the effects of an exogenous loosening of the borrowing constraint through lower required down payments are largely counterfactual. Interest rates do not fall, house prices barely increase and aggregate household leverage rises, rather than remaining constant. Nevertheless, the collateral constraint is a crucial ingredient of the model, since changes in house prices are due entirely to variation in their collateral value, which is positive only when the borrowing constraint binds.

In fact, the interaction between the two constraints, which is the main source of the model's dynamics, generates another interesting phenomenon. When the lending constraint is binding, lower down payments may lead to lower house prices, since in equilibrium borrowing cannot exceed the limited amount of available funds. Therefore, collateral values must fall when permissible leverage rises, so as to leave overall borrowing unchanged at the level dictated by the lending constraint. This surprising result points to the welldocumented reduction in required down payments in the mature phase of the boom, when the scope for further slackening of lending constraints was arguably limited, as a potential trigger for the turnaround in house prices that unleashed the financial crisis.

Although our account of the boom focuses primarily on the role of lending constraints, it does not rule out a contemporaneous loosening of collateral requirements for marginal borrowers of the kind documented by Duca et al. (2011), Favilukis et al. (2013) and Geanakoplos (2010) for instance. However, our results do imply that the aggregate impact of looser collateral requirements during the boom was smaller than that of the expansion in credit supply associated with the progressive erosion of the existing barriers to lending. If there was an increase in the demand for funds, the shift in credit supply must have been larger, or interest rates would have not fallen.

This paper's reconstruction of the facts that characterize the credit and housing boom is consistent with the microeconometric evidence of Mian and Sufi, 2009, 2011. They show that an expansion in credit supply was the fundamental driver of the surge in household debt, and that borrowing against the increased value of real estate by existing homeowners accounts for a significant fraction of this build-up in debt. Our model, with its emphasis on the role of lending as opposed to borrowing constraints, provides a clean theoretical framework to interpret this evidence and to asses its macroeconomic implications. Such a 
framework is particularly relevant because a large body of work has documented the far reaching repercussions of the boom and subsequent bust in household debt and in real estate values on other macroeconomic outcomes, such as defaults, consumption, employment, and even education (Mian and Sufi, 2010, 2014a,b, Mian et al., 2013, Baker, 2014, Charles et al., 2014a,b, Di Maggio et al., 2014, Palmer, 2014).

The rest of the paper is organized as follows. Section 1.1 reviews the literature. Section 2 presents our simple model of lending and borrowing with houses as collateral and a lending constraint. Section 3 analyzes the properties of this model and characterizes its equilibrium. Section 4 illustrates a number of quantitative experiments that compare the macroeconomic impact of looser lending and collateral constraints. Section 5 concludes.

1.1. Related Literature. This paper is related to the recent macroeconomic literature on the causes and consequences of the financial crisis. As in Eggertsson and Krugman (2012), Guerrieri and Lorenzoni (2012), Hall (2012), Midrigan and Philippon (2011), Favilukis et al. (2013), Boz and Mendoza (2014), Justiniano et al. (2014a,b), and Huo and Rios-Rull (2014), we use a model of household borrowing to analyze the drivers of the boom and bust in credit and house prices that precipitated the Great Recession. ${ }^{4}$

We follow these studies by limiting borrowing through a collateral constraint à la Kiyotaki and Moore (1997), which is backed by houses as in Iacoviello (2005) and Campbell and Hercowitz (2009b). What is new in our framework is the introduction of the lending constraint, as a device to model the expansion in credit supply first documented by Mian and Sufi (2009). The interaction of this new constraint with the standard borrowing limit generates rich patterns of debt and home values that significantly improve the model's ability to match the four fundamental facts about the boom highlighted above, even in an extremely simple economy. Moreover, the interplay between the constraints provides an interesting insight on how the boom might have turned into bust, with the deterioration in credit standards at the peak of the cycle triggering a fall in house prices.

This interaction between constraints also sets our work apart from Kiyotaki et al., 2011, Adam et al. (2012), Garriga et al. (2012) and Kermani (2012). They study the effects of a

\footnotetext{
${ }^{4}$ Our paper is also broadly related to the work of Gerali et al. (2010) and Iacoviello (2014), who estimate large-scale dynamic stochastic general equilibrium models with several nominal and real frictions, including collateral constraints for households and entrepreneurs, and leverage restrictions for financial intermediaries. These papers, however, investigate the properties of business cycles, and do not focus on the recent boombust cycle.
} 
reduction in the world interest rate on a small open economy with borrowing constraints. These effects are qualitatively similar to those of looser lending constraints in our framework, but they treat the decline in interest rates as exogenous. In our model, in contrast, lower interest rates result from a slacker lending constraint when the borrowing limit is binding, thus connecting the fall in mortgage rates to the financial liberalization and other well documented domestic, rather than just international, developments.

Another novelty of our approach is that we model the financial liberalization of the early 2000s as a slackening of the lending constraint. This is in contrast with literature cited above, which tends to capture variation in the availability of credit in both phases of the cycle through changes in the tightness of the borrowing constraint. ${ }^{5}$

We deviate from this widespread practice and focus on looser lending constraints as the driver of the credit boom for two reasons. First, the microeconometric evidence of Ambrose and Thibodeau (2004), Mian and Sufi (2009), Favara and Imbs (2012) and Di Maggio and Kermani (2014) clearly points to a shift in credit supply as a key factor behind the surge in debt and house prices. A slackening of lending constraints captures this credit supply shift cleanly and intuitively. Second, in models with a borrowing constraint à la Kiyotaki and Moore (1997), looser collateral requirements increase the demand for credit, putting upward pressure on interest rates, which is counterfactual.

The reference to looser collateral requirements as a credit demand shock might sound surprising, since required down payments are set by financial intermediaries, and hence are usually taken to reflect credit supply conditions. Therefore, it would seem plausible that an increase in banks' ability to lend prompted them to accept lower down payments. This intuitive link between collateral requirements and lending limits is absent in the workhorse model of collateralized borrowing of Kiyotaki and Moore (1997), but it might play a role in practice, connecting the movements in the demand and supply of credit as defined in our framework. Even if this were the case, however, our results suggest that a satisfactory account of the credit boom requires a larger shift in credit supply than in loan demand in response to their common determinants.

Our study also builds on the vast literature that focuses on the microeconomic foundations of leverage restrictions on financial intermediaries, in environments with agency,

\footnotetext{
${ }^{5}$ This modeling device is also the foundation of many recent normative studies on macroprudential regulation, such as Bianchi et al., 2012, Mendicino, 2012, Bianchi and Mendoza, 2012, 2013, Lambertini et al., 2013 Farhi and Werning, 2013, Korinek and Simsek, 2014.
} 
informational or incomplete market frictions (e.g. Holmstrom and Tirole, 1997, Adrian and Shin, 2008, Geanakoplos, 2010, Gertler and Kiyotaki, 2010, Gertler and Karadi, 2011, Christiano and Ikeda, 2013, Bigio, 2013, Simsek, 2013). As in Adrian and Shin (2010a), Gertler et al. (2012), Adrian and Boyarchenko (2012, 2013), Dewachter and Wouters (2012), He and Krishnamurthy (2013), and Brunnermeier and Sannikov (2014), we take these leverage restrictions as given. These papers focus on risk as the fundamental determinant of credit supply through its effects on asset prices and intermediaries' leverage, on their fragility when leverage rises in tranquil times, and on the consequences of this fragility when tranquility gives way to turbulence. Instead, we abstract from risk entirely, to concentrate on the link between the availability of credit, household debt and home prices. The result is a very simple model of the causes of the credit and housing boom, and of a possible trigger of its demise. Central to our findings is the interplay between lending and borrowing constraints, which is absent in this literature.

The paper closest to ours is Landvoigt (2014), who also stresses the interaction between supply and demand of mortgage debt. He proposes a rich model of borrowing and lending with intermediation, mostly focused on the effects of securitization on mortgage finance over the past several decades. In his model, mortgages can default and securitization allows to transfer this risk from leverage-constrained intermediaries to savers with low risk aversion. The final section of his paper studies the boom and bust of the 2000s, as we do here. In this experiment, the credit cycle is driven by a slackening of collateral requirements, along with a perceived decline in the riskiness of mortgages, which turns out to be incorrect. This combination of shocks generates a boom and bust in debt and real estate values that is qualitatively plausible. However, the response of house prices is small, partly because the yield on mortgage backed securities rises during the boom. This effect on mortgage rates is at odds with the data (fact 4), and it is presumably due to the slackening of the collateral constraint, which puts upward pressure on interest rates, as suggested by our model.

Risk is also central to the analysis of Favilukis et al. (2013), who present a life cycle model with idiosyncratic income fluctuations and incomplete markets. In their framework, a loosening of borrowing constraints, together with lower transaction costs for housing, increases home prices by compressing their risk premium, since it improves the ability of households to insure against income risk. This effect is large enough to account for most of the rise in real estate prices during the boom, but it is accompanied by an increase in 
interest rates, since better risk sharing opportunities decrease precautionary saving, thus increasing the demand for funds. To reverse this counterfactual increase in interest rates, the model also needs an infusion of foreign capital to shift the supply of credit.

\section{THE MODEL}

This section presents a simple model with heterogeneous households that borrow from each other, using houses as collateral. We use the model to establish that the crucial factor behind the boom in house prices and mortgage debt of the early 2000s was an outward shift in the supply of funds to borrowers, rather than an increase in the their demand driven by lower collateral requirements, as mostly assumed by the literature so far. We illustrate this insight in a simple endowment economy, without the unnecessary complications arising from production and capital accumulation.

2.1. Objectives and constraints. The economy is populated by two types of households, with different discount rates, as in Kiyotaki and Moore (1997), Iacoviello (2005), Campbell and Hercowitz (2009b) and our own previous work (Justiniano, Primiceri, and Tambalotti, 2014b,a). Patient households are denoted by $l$, since in equilibrium they save and lend. Their discount factor is $\beta_{l}>\beta_{b}$, where $\beta_{b}$ is the discount factor of the impatient households, who borrow in equilibrium.

Representative household $j=\{b, l\}$ maximizes utility

$$
E_{0} \sum_{t=0}^{\infty} \beta_{j}^{t}\left[u\left(c_{j, t}\right)+v_{j}\left(h_{j, t}\right)\right],
$$

where $c_{j, t}$ denotes consumption of non-durable goods, and $v_{j}\left(h_{j, t}\right)$ is the utility of the service flow derived from a stock of houses $h_{j, t}$ owned at the beginning of the period. The function $v(\cdot)$ is indexed by $j$ for reasons explained in section 2.3. Utility maximization is subject to the flow budget constraint

$$
c_{j, t}+p_{t}\left[h_{j, t+1}-(1-\delta) h_{j, t}\right]+R_{t-1} D_{j, t-1} \leq y_{j, t}+D_{j, t},
$$

where $p_{t}$ is the price of houses in terms of the consumption good, $\delta$ is the depreciation rate of the housing stock, and $y_{j, t}$ is an exogenous endowment of consumption goods and new houses. $D_{j, t}$ is the amount of one-period debt accumulated by the end of period $t$, and carried into period $t+1$, with gross interest rate $R_{t}$. In equilibrium, debt is positive for the 
impatient borrowers and it is negative for the patient lenders, representing loans that the latter extend to the former. Borrowers can use their endowment, together with loans, to buy non-durable consumption goods and new houses, and to repay old loans with interest.

Households' decisions are subject to two more constraints. First, on the liability side of their balance sheet, a collateral constraint limits debt to a fraction $\theta$ of the value of the borrowers' housing stock, along the lines of Kiyotaki and Moore (1997). This constraint takes the form

$$
D_{j, t} \leq \theta p_{t} h_{j, t+1}
$$

where $\theta$ is the maximum allowed loan-to-value (LTV) ratio. ${ }^{6}$ Therefore, changes in $\theta$ affect households' ability to borrow against a given value of their property. In practice, higher values of $\theta$ capture looser collateral requirements, such as those associated with lower down payments, multiple mortgages on the same property (so-called piggy back loans), and more generous home equity lines of credit. A growing literature identifies changes in $\theta$, and in the credit conditions that they represent, as an important driver of the credit cycle of the 2000s. Recent papers based on this hypothesis include Eggertsson and Krugman (2012), Guerrieri and Lorenzoni (2012), Hall (2012), Midrigan and Philippon (2011), Garriga et al. (2012), Favilukis et al. (2013), and Boz and Mendoza (2014).

The second constraint on households' decisions applies to the asset side of their balance sheet, in the form of an upper bound on the total amount of mortgage lending that they can extend

$$
-D_{j, t} \leq \bar{L}
$$

This lending constraint is meant to capture a variety of implicit and explicit regulatory, institutional and technological constraints on the economy's ability to channel funds towards the mortgage market. ${ }^{7}$

\footnotetext{
${ }_{6}$ This type of constraint is often stated as a requirement that contracted debt repayments (i.e. principal plus interest) do not exceed the future expected value of the collateral. We focus on a contemporaneous constraint for simplicity. This choice is inconsequential for the results, which mostly pertain to steady state equilibria.

${ }^{7}$ In our stylized economy, this constraint also represents a limit on households' overall ability to save. This equivalence is an artifact of the assumption that mortgages are the only financial asset in the economy, but it is not important for the results.
} 
For simplicity, we impose this constraint directly on the ultimate lenders. However, appendix $\mathrm{B}$ shows that this formulation is equivalent to one in which financial intermediaries face a leverage (or capital) constraint and a cost of equity adjustment. When this cost becomes very large, the leverage constraint on intermediaries boils down to a lending constraint of the form (2.2), producing identical results to those in the baseline model.

This extreme formulation of the lending constraint is meant to create a stark contrast with the more familiar collateral constraint imposed on the borrowers. From a macroeconomic perspective, the lending limit produces an upward sloping supply of funds in the mortgage market, which mirrors the downward sloping demand for credit generated by the borrowing constraint. We illustrate this point in the next section, which characterizes the equilibrium of the model. In section 4, we will use the implications of this equilibrium to argue that the boom in credit and house prices of the early 2000s is best understood as the consequence of looser constraints on lending, rather than on borrowing: an increase in $\bar{L}$, rather than in $\theta$.

2.2. Equilibrium conditions. Given their lower propensity to save, impatient households borrow from the patient in equilibrium. Therefore, the lending constraint (2.2) does not influence their decisions, which obey the following optimality conditions

$$
\begin{gathered}
\left(1-\mu_{t}\right) u^{\prime}\left(c_{b, t}\right)=\beta_{b} R_{t} E_{t} u^{\prime}\left(c_{b, t+1}\right) \\
\left(1-\mu_{t} \theta\right) u^{\prime}\left(c_{b, t}\right) p_{t}=\beta_{b} v_{b}^{\prime}\left(h_{b, t+1}\right)+\beta_{b}(1-\delta) E_{t}\left[u^{\prime}\left(c_{b, t+1}\right) p_{t+1}\right] \\
c_{b, t}+p_{t}\left[h_{b, t+1}-(1-\delta) h_{b, t}\right]+R_{t-1} D_{b, t-1}=y_{b, t}+D_{b, t} \\
\mu_{t}\left(D_{b, t}-\theta p_{t} h_{b, t+1}\right)=0, \quad \mu_{t} \geq 0, \quad D_{b, t} \leq \theta p_{t} h_{b, t+1},
\end{gathered}
$$

where $u^{\prime}\left(c_{b, t}\right) \cdot \mu_{t}$ is the Lagrange multiplier on the collateral constraint.

Equation (2.3) is a standard Euler equation weighting the marginal benefit of higher consumption today against the marginal cost of lower consumption tomorrow. Relative to the case of an unconstrained consumer, the cost of a tighter borrowing constraint, as measured by the multiplier $\mu_{t}$, reduces the benefit of higher current consumption, leading the impatient to consume less than they otherwise would. Equation (2.4) characterizes 
housing demand by the borrowers. It equates the cost of the consumption foregone to purchase an additional unit of housing, with the benefit of enjoying this house tomorrow, and then selling it (after depreciation) in exchange for goods. The term $\left(1-\mu_{t} \theta\right)$ on the left-hand side of (2.4) reduces the cost of foregone consumption, as the collateral value of the newly purchased unit of housing slackens the borrowing constraint. Equation (2.4) shows that the value of a house to a borrower is increasing in the tightness of the borrowing constraint $\left(\mu_{t}\right)$ and the maximum admissible loan-to-value-ratio $(\theta)$. Finally, equation (2.5) is the flow budget constraint of the borrower, while the expressions in (2.6) are the complementary slackness conditions for the collateral constraint.

Since patient households lend in equilibrium, their decisions are influenced by the lending constraint. Their equilibrium conditions are

$$
\begin{gathered}
\left(1+\xi_{t}\right) u^{\prime}\left(c_{l, t}\right)=\beta_{l} R_{t} E_{t} u^{\prime}\left(c_{l, t+1}\right) \\
u^{\prime}\left(c_{l, t}\right) p_{t}=\beta_{l} v_{l}^{\prime}\left(h_{l t+1}\right)+\beta_{l}(1-\delta) E_{t}\left[u^{\prime}\left(c_{l, t+1}\right) p_{t+1}\right] \\
c_{l, t}+p_{t}\left[h_{l, t+1}-(1-\delta) h_{l, t}\right]+R_{t-1} D_{l, t-1}=y_{l, t}+D_{l, t} \\
\xi_{t}\left(-D_{l, t}-\bar{L}\right)=0, \quad \xi_{t} \geq 0, \quad-D_{l, t} \leq \bar{L},
\end{gathered}
$$

where $u^{\prime}\left(c_{l, t}\right) \cdot \xi_{t}$ is the Lagrange multiplier on the lending constraint. When this constraint is binding, the lenders would like to save more at the prevailing interest rate, but they cannot. The multiplier $\xi_{t}$ then boosts the marginal benefit of current consumption in their Euler equation (2.7), making it optimal to consume what they would rather save. Equivalently, when the lending constraint binds, $\xi_{t}$ reduces the lenders' perceived rate of return from postponing consumption, enticing them to tilt their consumption profile towards the present. This effect is in contrast with what happens to the borrowers, who must be dissuaded from consuming more today so as not to violate their borrowing constraint. Unlike the collateral constraint, though, the lending constraint does not affect the demand for houses, since the lending limit does not depend on their value. Otherwise, equations (2.7)-(2.10) have similar interpretations to (2.3)-(2.6). 
The model is closed by imposing that borrowing is equal to lending

$$
D_{b, t}+D_{l, t}=0
$$

and that the housing market clears

$$
h_{b, t}+h_{l, t}=\bar{h}
$$

where $\bar{h}$ is a fixed supply of houses.

2.3. Functional forms. To characterize the equilibrium of the model, we make two convenient functional form assumptions. First, we assume that the lenders' utility function implies a rigid demand for houses at the level $\bar{h}_{l}{ }^{8}$ Consequently, we replace equation (2.8) with

$$
h_{l, t}=\bar{h}_{l} .
$$

In this equilibrium, houses are priced by the borrowers, who are leveraged and face a fixed supply equal to $\bar{h}_{b} \equiv \bar{h}-\bar{h}_{l}$. This assumption and its implications for the equilibrium are appealing for two reasons. First, housing markets are highly segmented (e.g. Landvoigt et al., 2013), so that in practice there is little trading of houses between rich and poor agents, lenders and borrowers. Assuming a rigid demand by the lenders shuts down all trading between the two groups, thus approximating reality. Second, this simple modeling device captures the idea that houses are priced by the most leveraged individuals, as in Geanakoplos (2010), amplifying the potential effects of borrowing constraints on house prices. $^{9}$

The second simplifying assumption is that utility is linear in non-durable consumption. As a result, the marginal rate of substitution between houses and non-durables does not depend on the latter. Furthermore, the level and distribution of income do not matter for the equilibrium in the housing and debt markets, which makes the determination of house

\footnotetext{
${ }^{8}$ This is the reason why the utility from housing services $v$ is indexed by $j$.

${ }^{9}$ Alternatively, one could assume that borrowers and lenders enjoy two different kinds of houses, which are traded in two separate markets. In this environment, shifts in either the lending or the borrowing limit would only affect the price of the borrowers' houses, through their impact on the multiplier. This result is consistent with the evidence in Landvoigt et al. (2013), according to which cheaper houses (presumably those owned by borrowers) appreciated more than more expensive ones.
} 
prices simple and transparent. Re-arranging equation (2.4), we now have

$$
p_{t}=\frac{\beta_{b}}{\left(1-\mu_{t} \theta\right)}\left[m r s+(1-\delta) E_{t} p_{t+1}\right]
$$

where $m r s=v^{\prime}\left(\bar{h}-\bar{h}_{l}\right)$, and the constant marginal utility of consumption was normalized to one.

According to this expression, house prices are the discounted sum of two components: first, the marginal rate of substitution between houses and consumption, which represents the "dividend" from living in the house, and is also equal to their shadow rent; second, the expected selling price of the undepreciated portion of the house. The discount factor, in turn, depends on the maximum LTV ratio, $\theta$, and on the multiplier of the collateral constraint, $\mu_{t}$. Therefore, house prices are increasing in the fraction of the house that can be used as collateral and in the tightness of the borrowing constraint.

Although it is extreme, the assumption of linear utility simplifies the mathematical structure of the model significantly, making its economics particularly transparent, especially in terms of the determinants of house prices. With a constant shadow rent ( $m r s$, house prices can only vary due to fluctuations in the discount factor. This feature of the model is consistent with the fact that house prices are significantly more volatile than measured fundamentals, resulting in large fluctuations of price-rent ratios, as stressed for instance by Favilukis et al. (2013).

Unlike in Favilukis et al. (2013), though, the discount factor in (2.12) does not depend on risk, but on the tightness of the borrowing constraint, both through the multiplier $\mu_{t}$ and the LTV ratio $\theta$. In our quantitative experiments, movements in $\mu_{t}$ associated with shifts in the lending limit $\bar{L}$ account for a large portion of the surge in house prices between 2000 and 2006, even if we abstract from risk entirely. This result, of course, does not rule out an important role for risk in the pricing of houses over regular business cycles, nor over the housing boom more specifically. However, it does suggest that a relaxation of lending limits is a more promising approach to modeling the type of credit liberalization experienced by the US economy since the late 1990s, than an increase in LTVs. Exploring the effects of looser lending constraints in a model with risk along the lines of Favilukis et al. (2013) would be an interesting avenue for future research. 


\section{Characterization of the Equilibrium}

The model of the previous section features two balance sheet constraints, both limiting the equilibrium level of debt in the economy. The collateral constraint on the liability side of households' balance sheets limits the amount of borrowing to a fraction of the value of their houses $\left(D_{b, t} \leq \theta p_{t} \bar{h}_{b}\right)$. This is a standard tool used in the literature to introduce financial frictions. The lending constraint, instead, puts an upper bound on the ability of savers to extend mortgage credit. But in our closed economy, where borrowing must be equal to lending in equilibrium, the lending limit also turns into a constraint on borrowing $\left(D_{b, t} \leq \bar{L}\right) .{ }^{10}$ Which of the two constraints binds at any given point in time depends on the parameters $\theta$ and $\bar{L}$, but also on house prices, which are endogenous. Moreover, both constraints bind when $\theta p_{t} \bar{h}_{b}=\bar{L}$, a restriction that turns out to be far from knife-edge, due to the endogeneity of $p_{t}$.

To illustrate the interaction between the two balance sheet constraints, we start from the standard case with only a borrowing limit, which is depicted in figure 3.1. The supply of funds is perfectly elastic at the interest rate represented by the (inverse of the) lenders' discount factor. The demand for funds is also flat, at a higher interest rate determined by the borrowers' discount factor. At the borrowing limit, however, credit demand becomes vertical. Therefore, the equilibrium is at the (gross) interest rate $1 / \beta_{l}$, where demand meets supply and the borrowing constraint is binding, implying a positive multiplier on the collateral constraint $\left(\mu_{t}>0\right)$. In this equilibrium, the price of houses is determined by equation (2.12), pinning down the location of the kink in the demand for funds.

Figure 3.2 extends the analysis to a model with a lending constraint. Now the supply of funds also has a kink, at the value $\bar{L}$. Whether this constraint binds in equilibrium depends on the relative magnitude of $\bar{L}$ and $\theta p_{t} \bar{h}_{b}$. In figure $3.2, \bar{L}>\theta p_{t} \bar{h}_{b}$, so that the lending constraint does not bind and the equilibrium is the same as in figure 3.1. ${ }^{11}$

If instead $\bar{L}<\theta p_{t} \bar{h}_{b}$, the lending limit is binding, as shown in figure 3.3. The interest rate now settles at $1 / \beta_{b}$, higher than before. At this rate of return, savers would be happy to expand their mortgage lending, but they cannot. At the same time, borrowers are not limited in their ability to bring consumption forward by the value of their collateral,

\footnotetext{
${ }^{10}$ In an open economy model with borrowing from abroad, such as Justiniano et al. (2014b), this constraint would become $D_{b, t} \leq \bar{L}+L_{f, t}$, where $L_{f, t}$ denotes the amount of foreign borrowing. Therefore, in such a model, $L_{f, t}$ plays a similar role to $\bar{L}$ in relaxing or tightening the constraint.

${ }^{11}$ For this to be an equilibrium, the resulting house price must of course satisfy $\bar{L}>\theta p_{t} \bar{h}_{b}$.
} 


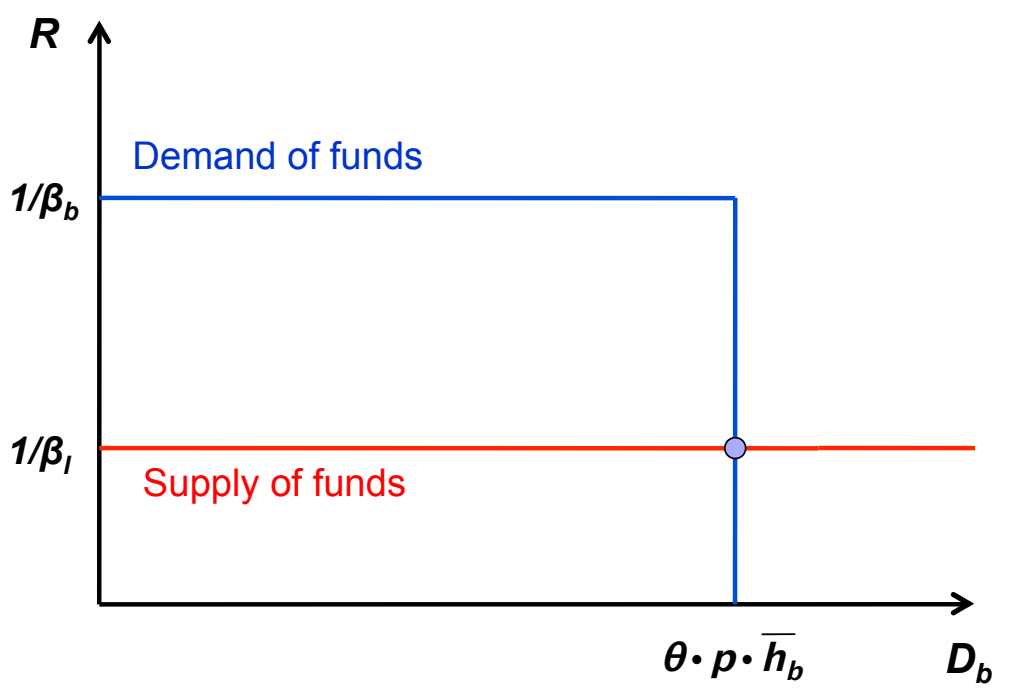

FiguRE 3.1. Demand and supply of funds in a model with collateral constraints.

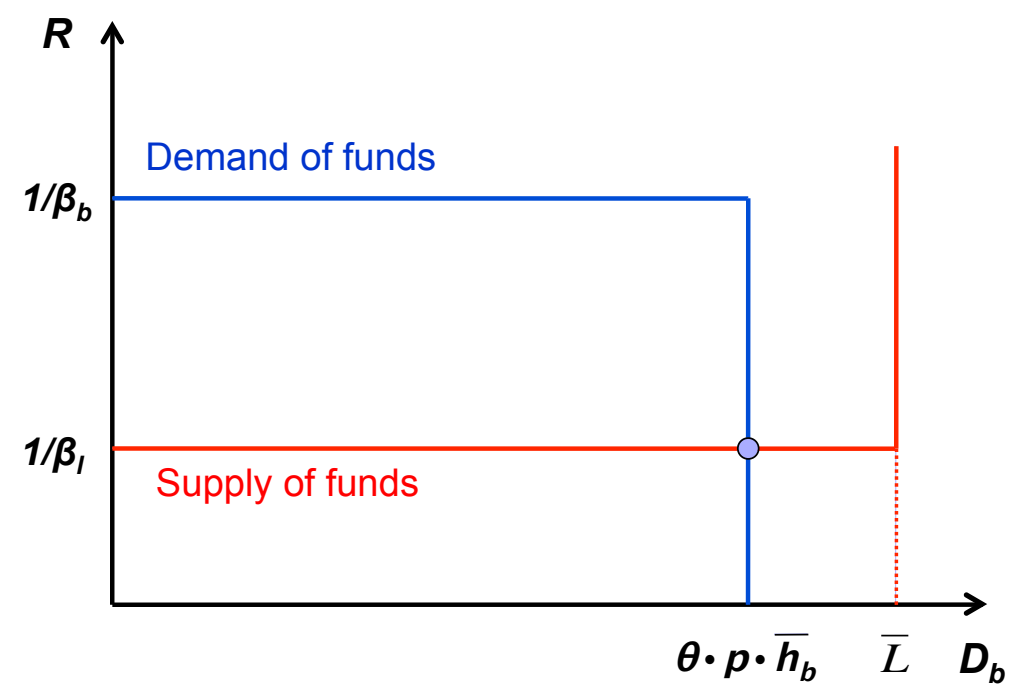

FIGURE 3.2. Demand and supply of funds in a model with collateral and lending constraints. The lending constraint is not binding.

but by the scarcity of funds that the savers can channel towards the mortgage market. Equation (2.12) again determines the price of houses. However, this price is below that in the scenarios illustrated in figures 3.1 and 3.2, since now the borrowing constraint does not bind (i.e. $\mu_{t}=0$ ). In this equilibrium, house prices are low because real estate is not valuable as collateral at the margin. An extra unit of housing does not allow any extra borrowing, since the binding constraint is on the supply side of the financial market. 


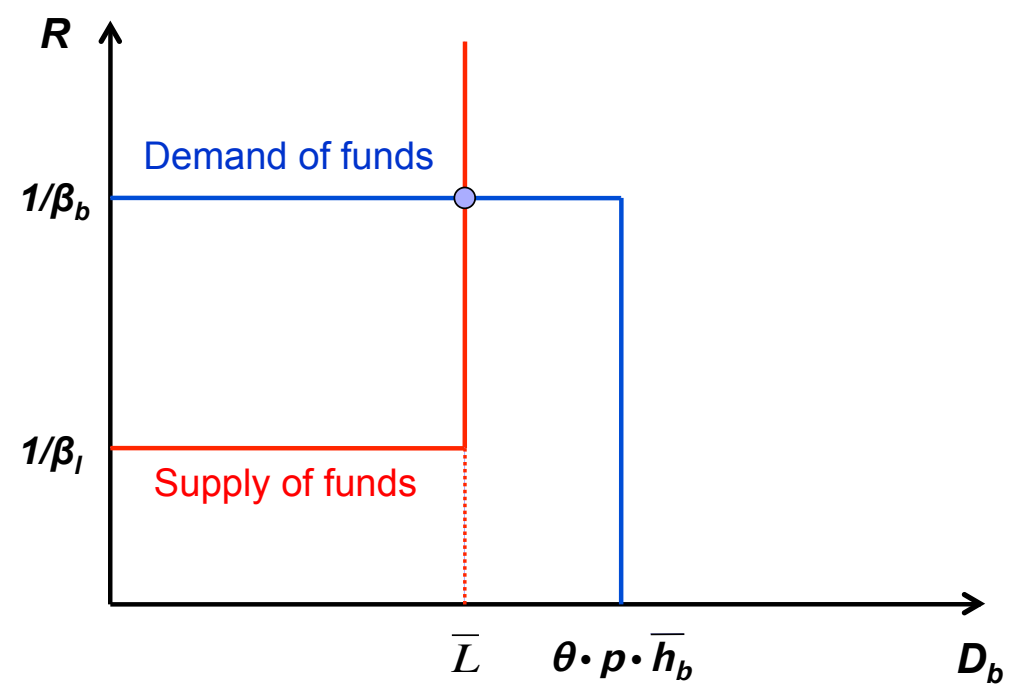

FIgURE 3.3. Demand and supply of funds in a model with collateral and lending constraints. The lending constraint is binding.

Qualitatively, the transition from a steady state with a low $\bar{L}$, as in figure 3.3 , to one with a higher $\bar{L}$, as in figure 3.2, causes interest rates to fall while household debt and house prices increase. This matches well the U.S. experience in the first half of the 2000s. Section 4 shows that this match also works quantitatively, and that a slackening of the constraint on mortgage lending is also consistent with other patterns in the data.

In contrast, a slackening of the borrowing constraint through an increase in the LTV parameter $\theta$ may result in higher interest rates and lower house prices, making it an unlikely source of the U.S. housing boom in the 2000s. To see this, assume that the borrowing constraint binds initially, as in figure 3.2. A sufficiently large increase in $\theta$ pushes interest rates up from $1 / \beta_{l}$ to $1 / \beta_{b}$, as the vertical "arm" of the demand for funds crosses over the lending limit $\bar{L}$, causing that constraint to bind. With the borrowing constraint no longer binding, the multiplier $\mu_{t}$ falls to zero, putting downward pressure on house prices. ${ }^{12}$

Intuitively, an increase in $\theta$ expands the demand for credit, driving its price, the interest rate, higher. And with higher interest rates, house prices fall. On the contrary, an increase in the lending limit $\bar{L}$ expands the supply of funds from lenders, pushing interest rates down, and debt and house prices up, leaving the debt-to-collateral ratio approximately unchanged.

\footnotetext{
${ }^{12}$ Starting instead from a situation in which the lending constraint is binding, as in figure 3.3 , an increase in $\theta$ would leave the equilibrium unchanged.
} 
Before moving on, it is useful to consider the case in which $\bar{L}=\theta p_{t} \bar{h}_{b}$, when the vertical arms of the supply and demand for funds exactly overlap. This is not an unimportant knife-edge case, as the equality might suggest, due to the endogeneity of home prices. In fact, there is a large and interesting region of the parameter space in which both constraints bind, so that $p_{t}=\frac{\bar{L}}{\theta \bar{h}_{b}}$. Given $p_{t}$, equation (2.12) pins down the value of the multiplier $\mu_{t}$, which, in turn, determines a unique interest rate

$$
R_{t}=\frac{1-\mu_{t}}{\beta_{b}}
$$

via equation (2.3). This is an equilibrium as long as the implied value of $\mu_{t}$ is positive, and the interest rate lies in the interval $\left[1 / \beta_{l}, 1 / \beta_{b}\right]$.

We formalize these intuitive arguments through the following proposition.

Proposition 1. There exist two threshold house prices, $\underline{p} \equiv \frac{\beta_{b} m r s}{1-\beta_{b}(1-\delta)}$ and $\bar{p}(\theta) \equiv \frac{\tilde{\beta}(\theta) m r s}{1-\tilde{\beta}(\theta)(1-\delta)}$, such that:

(i) if $\bar{L}<\theta \underline{p} \bar{h}_{b}$, the lending constraint is binding and

$$
p_{t}=\underline{p}, \quad D_{b, t}=\bar{L} \quad \text { and } \quad R_{t}=\frac{1}{\beta_{b}}
$$

(ii) if $\bar{L}>\theta \bar{p}(\theta) \bar{h}_{b}$, the borrowing constraint is binding and

$$
p_{t}=\bar{p}(\theta), \quad D_{b, t}=\theta \bar{p}(\theta) \bar{h}_{b} \quad \text { and } \quad R_{t}=\frac{1}{\beta_{l}} ;
$$

(iii) if $\theta \underline{p}_{b} \leq \bar{L} \leq \theta \bar{p}(\theta) \bar{h}_{b}$, both constraints are binding and

$$
p_{t}=\frac{\bar{L}}{\theta \bar{h}_{b}}, \quad D_{b, t}=\bar{L} \quad \text { and } \quad R_{t}=\frac{1}{\beta_{b}}\left[1-\frac{1-\beta_{b}(1-\delta)-m r s \cdot \beta_{b} \theta \bar{h}_{b} / \bar{L}}{\theta}\right]
$$

where $m r s \equiv v^{\prime}\left(\bar{h}-\bar{h}_{l}\right), \tilde{\beta}(\theta) \equiv \frac{\beta_{b} \beta_{l}}{\theta \beta_{b}+(1-\theta) \beta_{l}}$ and $\bar{p}(\theta) \geq \underline{p}$ for every $\theta \geq 0$.

Proof. See appendix A.

As a further illustration of Proposition 1, figure 3.4 plots the equilibrium value of house prices, debt and interest rates, as a function of the lending limit $\bar{L}$, for a constant LTV ratio $\theta$. The equilibrium behavior of these variables features three regions. Starting from the left in the figure, the lending limit is binding while the borrowing limit is not (case i). With a tight lending constraint, interest rates are high, while house prices and debt are low. As $\bar{L}$ rises past $\theta p \bar{h}_{b}$ and lending constraints become looser, both constraints 

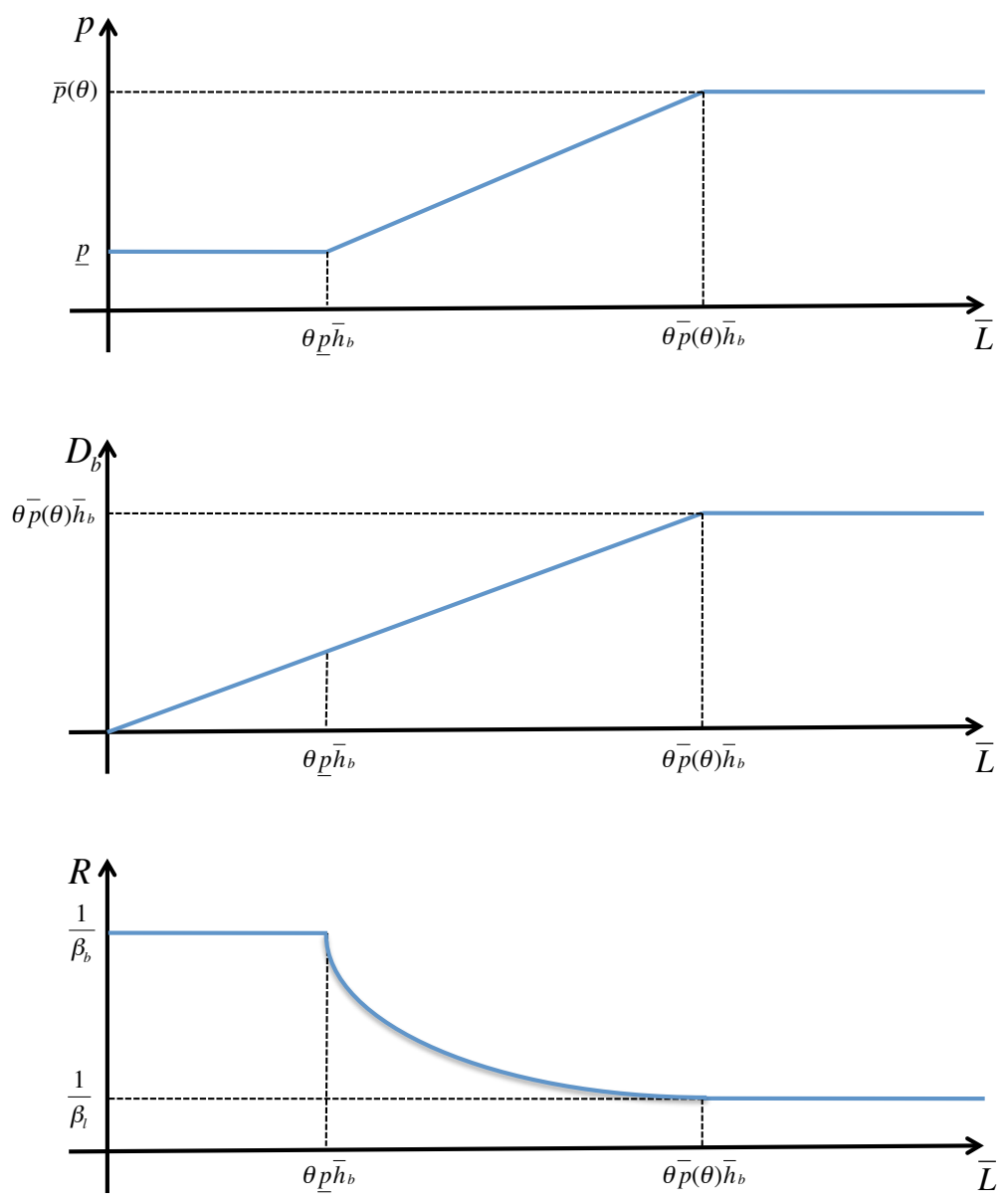

FIGURE 3.4. Real house price, debt and interest rates as a function of $\bar{L}$, given $\theta$.

start binding (case iii). In this middle region, interest rates fall and the collateral value of houses rises, boosting their price and hence households' ability to borrow. However, the relationship between lending limits and house prices is not strictly monotonic. With further increases in $\bar{L}$, eventually only the borrowing constraint binds (case ii). In this region, the model becomes a standard one with only collateral constraints, in which lending limits are irrelevant for the equilibrium.

The qualitative implications of the transition towards looser lending constraints illustrated in figure 3.4 square well with the four stylized facts outlined in the introduction: higher house prices and debt, a stable debt-to-collateral ratio and lower interest rates. The next section calibrates the model to analyze its quantitative performance. 


\begin{tabular}{ccccc}
\hline$\delta$ & $\beta_{b}$ & $\beta_{l}$ & $\theta$ & $\rho$ \\
0.003 & 0.9879 & 0.9938 & 0.80 & 0.0056 \\
\hline
\end{tabular}

TABLE 1. Model calibration.

\section{QUANTITATIVE ANALYSIS}

This section provides a quantitative perspective on the simple model introduced above. The model is parametrized so that its steady state matches key statistics for the 1990s, a period of relative stability for the quantities we are interested in. We associate this steady state with a tight lending constraint, as in figure 3.3. This assumption seems appropriate for a period in which mortgage finance was still relatively unsophisticated, securitization was still developing, and as a result savers faced relatively high barriers to investing in mortgage-backed finance.

Starting from this steady state, we analyze the extent to which a lowering of these barriers, in the form of a progressive increase in the lending limit $\bar{L}$, generates the stylized facts of the housing and debt boom between 2000 and 2006. The main conclusion we draw from this experiment is that looser lending constraints are a crucial ingredient in the dynamics of debt, house prices and interest rates in the period leading up to the financial crisis. In contrast, a slackening of borrowing limits through higher loan-to-value ratios has implications largely at odds with those same stylized facts. In fact, in our framework, a relaxation of collateral requirements at the peak of the boom triggers a fall in house prices.

4.1. Parameter values. Table 1 summarizes the model's calibration, which is based on U.S. macro and micro targets.

Time is in quarters. We set the depreciation rate of houses $(\delta)$ equal to 0.003 , based on the NIPA Fixed Asset Tables. Real mortgage rates are computed as the difference between the 30-year nominal conventional mortgage rate, published by the Federal Reserve Board, and 10-year-ahead inflation expectations from the Survey of Professional Forecasters. The resulting series is plotted in figure 1.4. The average real rate in the 1990s is slightly less than $5 \%(4.63 \%)$ and falls by about $2.5 \%$ between 2000 and 2005 . Accordingly, we set the discount factor of the borrowers to match a $5 \%$ real rate in the initial steady state, implying $\beta_{b}$ equal to 0.9879 . Given this value, we calibrate the lenders' discount factor 
to generate a fall in interest rates of 2.5 percentage points following the relaxation of the lending constraint, yielding $\beta_{l}=0.9938$. The resulting gap in discount factors between patient and impatient households is in line with that chosen by Krusell and Smith (1998) or Carroll et al. (2013) to match the wealth distribution in the US.

For the calibration of the remaining parameter - the maximum allowed LTV ratio $(\theta)$ we face two main challenges, due to some aspects of the theoretical model that are stark simplifications of reality. First, the model assumes a collateral constraint with a constant loan-to-value ratio. This simple specification, which is the most popular in the literature, works well to provide intuition about the workings of the model, as in section 2. However, calibrating $\theta$ to the initial loan-to-value ratio of the typical mortgage, say around 0.8 , would overstate the aggregate debt-to-real estate ratio in the economy because, in reality, mortgage contracts require a gradual repayment of the principal over time. Consequently, average loan-to-value ratios in the data are lower than those observed at origination, since they reflect both new mortgages with relatively high LTVs and old mortgages whose principal has been largely paid down. ${ }^{13}$

To capture this feature of reality in our quantitative exercises, we follow Campbell and Hercowitz (2009b) and generalize the model by replacing the collateral constraint (2.1) with

$$
\begin{gathered}
D_{b, t} \leq \theta p_{t} \mathcal{H}_{b, t+1} \\
\mathcal{H}_{b, t+1}=\sum_{j=0}^{\infty}(1-\rho)^{j}\left[h_{t+1-j}-(1-\delta) h_{t-j}\right],
\end{gathered}
$$

where the last expression can be written recursively as

$$
\mathcal{H}_{b, t+1}=(1-\rho) \mathcal{H}_{b, t}+\left[h_{b, t+1}-(1-\delta) h_{b, t}\right]
$$

The variable $\mathcal{H}_{b, t+1}$ denotes the amount of housing stock that can be used as collateral at any point in time, which does not necessarily coincide with the physical stock of houses, $H_{b, t+1}$. Equation (4.2) describes the evolution and composition of $\mathcal{H}_{b, t+1}$. The houses built today $\left(h_{t+1}-(1-\delta) h_{t}\right)$ can all be pledged as collateral. Hence, they can "sustain" an amount of borrowing equal to a fraction $\theta$ of their market value. Over time, though, these houses loose their collateral "power" at a rate $\rho$. Only a fraction $(1-\rho)^{j}$ of the houses

\footnotetext{
$\overline{13}$ If we ignored this fact and calibrated $\theta$ as we do below, the effects of looser lending constraints would be even larger than in the baseline calibration.
} 
purchased in $t-j$ can be collateralized, with the remaining share representing amortization of the loan and the associated accumulation of home equity. If $\rho=\delta$, amortization and depreciation coincide, so that the entire housing stock can always be pledged. In this case $\mathcal{H}_{b, t+1}$ is equal to $H_{b, t+1}$ and the collateral constraint is identical to (2.1). If $\rho>\delta$, however, contractual amortization is faster than depreciation, leading to accumulation of equity, as in reality. This forced equity accumulation reduces the borrowing potential of the housing stock and the average debt-to-real estate ratio in the economy, for any given value of the initial LTV $\theta$. Appendix $\mathrm{C}$ characterizes the solution of the model with this generalized version of the collateral constraint.

The borrowing constraint with amortization that we just described features two parameters, $\theta$ and $\rho$, which allow the model to match information on maximum LTVs at origination, as well as on the average ratio of mortgages to the value of real estate among borrowers. To measure these objects, we first need to identify households in the data that resemble the borrowers in the model.

One straightforward option would be to call borrowers all households with mortgage debt, since only borrowers are indebted in the model. The problem with this strategy is that in the real world many mortgage borrowers also own a substantial amount of financial assets, which arguably makes them less severely constrained than the impatient borrowers in the model, who only own the equity in their house. In some cases, however, the assets held by these rich borrowers are illiquid, or otherwise unavailable to smooth consumption, which makes them behave as "hand-to-mouth" consumers, as discussed by Kaplan et al. (2014), Kaplan and Violante (2014),Campbell and Hercowitz (2009a), and Iacoviello and Pavan (2013).

In light of this evidence, we follow the more conservative strategy of calling "borrowers" the mortgage holders with limited liquid assets. We carry out this exercise in the Survey of Consumer Finances (SCF), which is a triennial survey of the assets and liabilities of U.S. households. Following Iacoviello and Pavan (2013) and Hall (2011), we set the limit on liquid assets at two months of total income, where liquid assets are the sum of money market, checking, savings and call accounts, directly held mutual funds, stocks, bonds, and T-Bills, net of credit card debt, as in Kaplan and Violante (2014).

Given this definition of borrowers, we calibrate the initial loan-to-value ratio, $\theta$, as the average LTV on "new" mortgages, which are those taken out by the borrowers in the year 
immediately preceding each survey. These new mortgages include both purchases and refinancings, but only if the amount borrowed is at least half the value of the house, since mortgages with lower initial LTVs are unlikely to be informative on the credit conditions experienced by marginal buyers (Campbell and Hercowitz, 2009b). A time-series average of these ratios computed over the three surveys of 1992, 1995 and 1998 yields a value for $\theta$ of 0.8 . This is a pretty standard initial LTV for typical mortgages and also broadly in line with the cumulative loan-to-value ratio of first-time home buyers estimated by Duca et al. (2011) for the 1990s.

For $\rho$, the parameter that governs the amortization speed on loans, we pick a value of 0.0056 to match the average ratio of debt to real estate for the borrowers in the three SCFs from the 1990s, which is equal to 0.43 . Finally, the lending limit $\bar{L}$ is chosen in the context of the experiments described in the next subsection.

4.2. An expansion in credit supply. This subsection studies the quantitative effects of a progressive relaxation of the lending constraint. As we discussed in the introduction, this relaxation captures in reduced form the many developments that made it easier for savings to flow towards the mortgage market, such as the large inflow of foreign funds, and the explosion of securitization and shadow banking. This so-called credit liberalization started well before the year 2000, but it accelerated significantly around the turn of the millennium.

The premise for this exercise is that at the end of the 1990s the U.S. economy was constrained by a limited supply of credit, as in figure 3.3 above. Starting in 2000, the lending constraint is gradually lifted, following the linear path depicted in figure 4.1. Each movement in $\bar{L}$ is unanticipated by the agents and the experiment is timed so that the lending constraint no longer binds in 2006. This timing is illustrated by the dotted part of the line in figure 4.1, which corresponds to periods in which the lending constraint is irrelevant for the equilibrium.

In the bare bones model presented above, an increase in $\bar{L}$ affects house prices and interest rates only in the region in which both the lending and borrowing constraints are binding, as demonstrated in proposition 1 . Therefore, the movements in $\bar{L}$ are calibrated to make this region coincide with the period between 2000 and 2006, when the four developments highlighted in the introduction were most evident. This modeling choice does not rule out the possibility that the relaxation of lending constraints started before 2000. Securitization, for instance, emerged in the late 1960s, although it did not become common place until the 


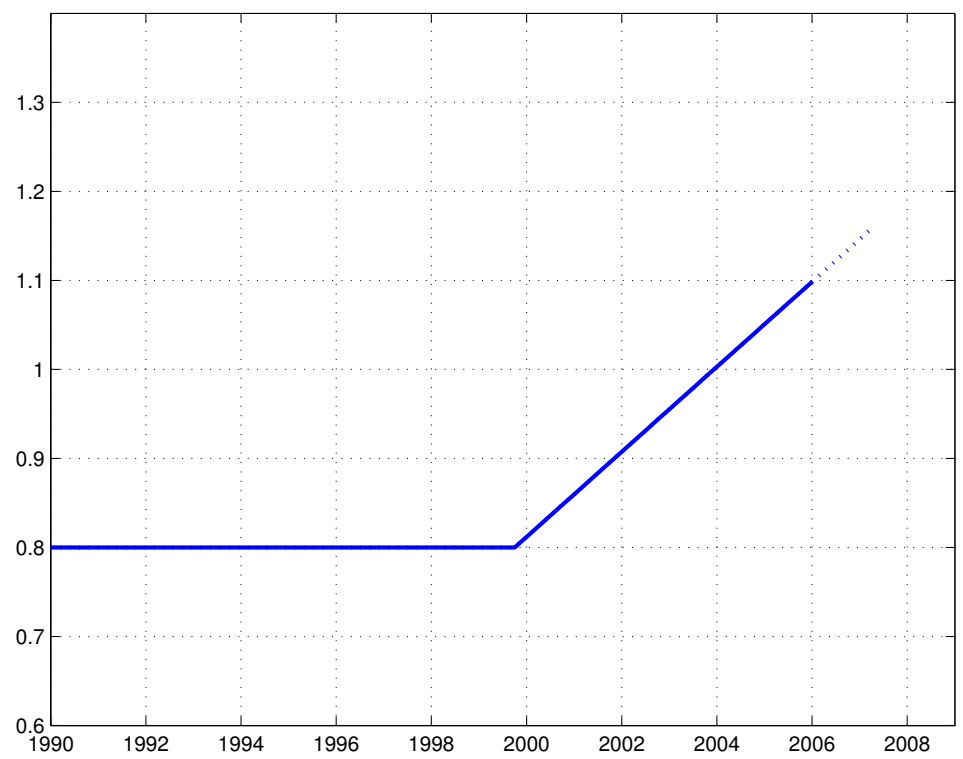

FigURE 4.1. Credit supply expansion. Evolution of the lending limit relative to GDP.

1990s. In this regard, the model suggests that this process of credit liberalization would have had relatively modest effects as long as the lending limit was far enough below the borrowing limit. This is why we ignore this earlier period in the simulations.

Figure 4.2 plots the response of the key variables in the model to the loosening of $\bar{L}$ described above. The expansion in credit supply lowers mortgage rates by 2.5 percentage points. This decline reflects the gradual transition from a credit-supply-constrained economy, where the interest rate equals $\frac{1}{\beta_{b}}$, to an economy that is constrained on the demand side of credit, with a lower interest rate $\frac{1}{\beta_{l}}$. This permanent fall in mortgage rates is a distinctive feature of our environment with lending constraints that cannot be replicated in standard models with only a borrowing limit, since their steady state interest rate is always pinned down by the discount factor of the lenders. Moreover, the magnitude of the decline is in line with the evidence presented in the introduction, but this is just a function of our calibration of the discount factors of the two sets of households.

As lending constraints become looser and mortgage rates fall below $\frac{1}{\beta_{b}}$, impatient households increase their demand for credit up to the limit allowed by the collateral constraint, which becomes binding. The lower the interest rate, the more desirable is borrowing and increasing today's consumption, and the higher becomes the shadow value $\mu_{t}$ of relaxing 

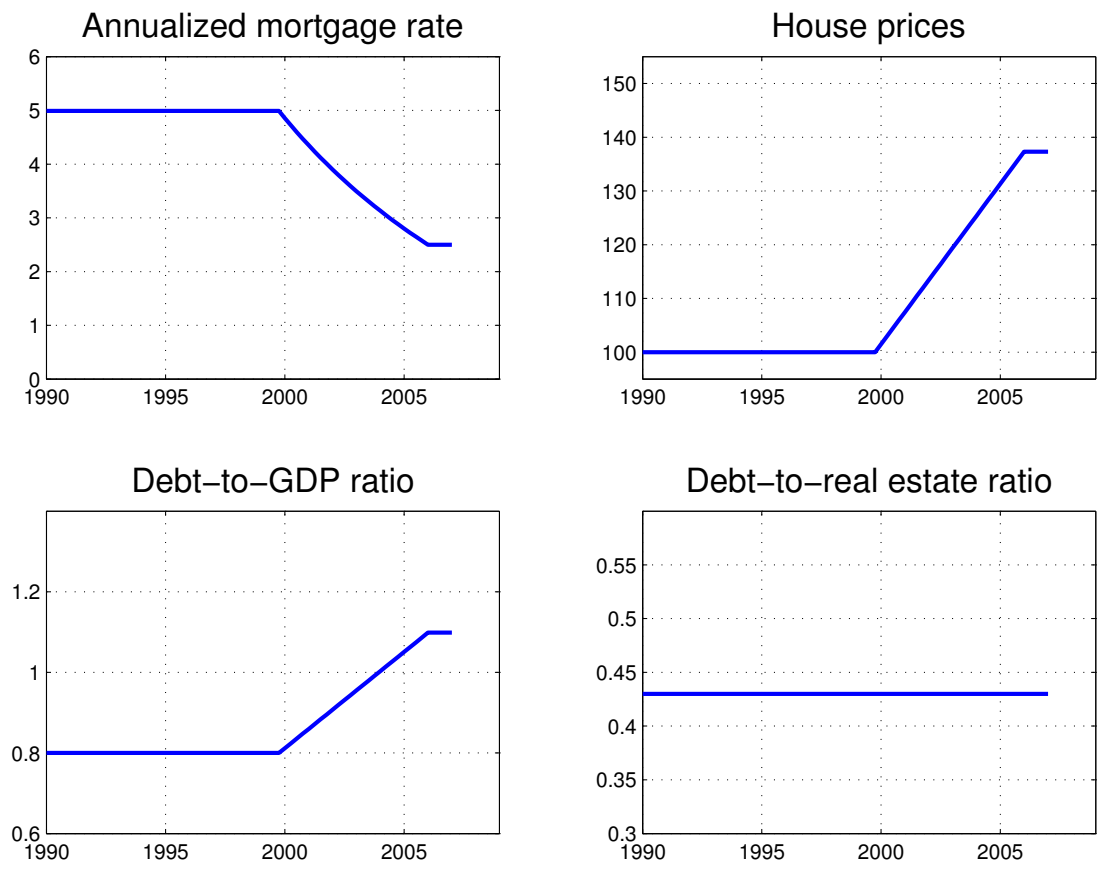

FIGURE 4.2. Credit supply expansion. Response of macro variables to the change in the lending limit depicted in figure 4.1.

the collateral constraint. According to equation (2.12), a rise in $\mu_{t}$ increases the value of houses to the borrowers, who are the agents pricing them, because their collateral services become more valuable.

In our calibration, house prices increase by almost 40 percent in real terms following the shift in credit supply, close to the U.S. experience depicted in figure 1.1. This substantial increase in house prices relaxes the collateral constraint in equilibrium, allowing households to borrow more against the higher value of their homes. In the model, mortgage debt rises by approximately 30 percentage points of GDP. However, the debt-to-real estate ratio remains unchanged, since debt and home values increase in parallel, as they did in the data shown in figure 1.3.

In summary, a progressive loosening of the lending constraint that generates an increase in household debt of 30 percentage points of GDP is associated with a large increase in house prices, a stable debt-to-collateral ratio, and a fall in mortgage rates, as in the four stylized facts of the boom. 
(a): Maximum LTV

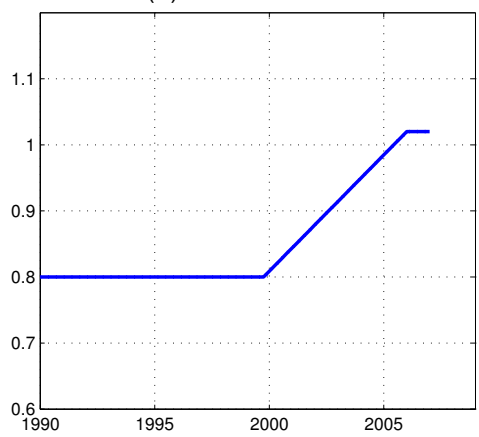

(b): Speed of repayment

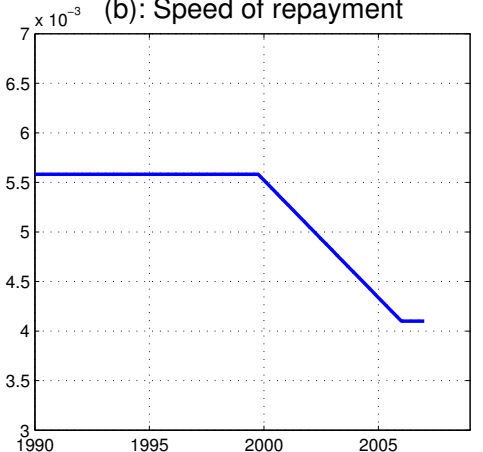

FIgURE 4.3. Looser collateral requirements. Evolution of the maximum LTV $(\theta)$ and of the speed of repayment $(\rho)$.

4.3. Looser collateral requirements. This section helps to put the success of the experiment we just presented in the right perspective by comparing its results to the implications of a loosening of borrowing limits. This comparison is especially important because much of the literature that studies the effect of credit liberalization on debt and house prices models this phenomenon as a loosening of collateral constraints.

To facilitate the comparison, we start the analysis in an economy without lending limits, which is parametrized to match the same targets as in section 4.1. This calibration produces the same values for most parameters, except for $\beta_{l}$ and $\beta_{b}$. In this model, the interest rate is pinned down at $\frac{1}{\beta_{l}}$, so we set $\beta_{l}$ at 0.9879 to match the 5 percent average real mortgage rate in the 1990s. For $\beta_{b}$ we choose the value 0.9820 to maintain the same gap from the discount factor of the lenders as in the previous experiment.

Given this parametrization, we study the effects of a gradual increase in the maximum LTV from 0.8 , the baseline value of $\theta$, to 1.02, as shown in panel a of figure 4.3. This change in $\theta$ is chosen to generate exactly the same increase in household debt as in the previous experiment, making the two simulations easily comparable.

The dashed lines in figure 4.4 illustrate the behavior of debt, interest rates and house prices in response to this change in $\theta$. The solid line replicates the paths from figure 4.2 , where the dynamics were driven by the relaxation of the lending constraint $\bar{L}$. The contrast between the solid and dashed responses highlights the remarkable ability of looser lending limits to generate the stylized facts of the boom, even in this extremely simple model.

In comparison, the variables of interest respond little to the $\theta$ increase, or in ways that are at odds with the data. First, interest rates are unchanged in this experiment, since 

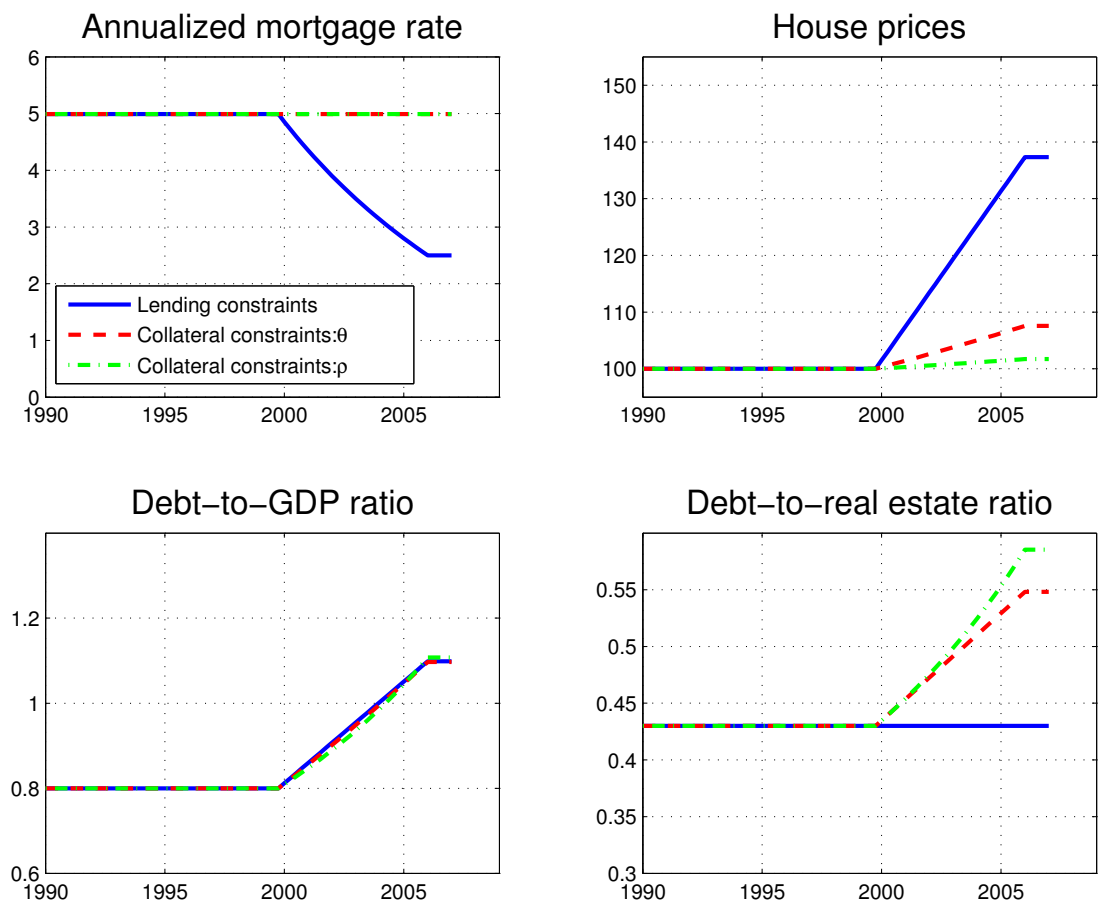

FIGURE 4.4. Response of macro variables to the change in collateral requirements depicted in figure 4.3, compared to the responses to the change in the lending limit.

lenders are unconstrained and their discount factor pins down the interest rate. In a model with short-run dynamics, for instance if agents were not risk neutral, interest rates would actually increase in the short-run to convince savers to lend additional funds to the now less constrained borrowers (e.g. Justiniano et al., 2014a). Second, house prices move little in response to an increase in the maximum LTV, which is consistent with the results of Iacoviello and Neri (2010), Kiyotaki et al. (2011) and Justiniano et al., 2014a. Consequently, the increase in household debt arises from a combination of slightly higher house prices and a rising debt-to-real estate ratio, as shown in the lower-right panel. The increase in the latter is counterfactual, as we have already stressed.

Results are very similar if the same increase in household debt is driven by a reduction in the speed of amortization $\rho$, rather than by a rise in $\theta$. This experiment delivers a looser borrowing constraint by increasing exogenously the stock of housing that can be pledged as collateral (equation 4.2). In this scenario, the change in $\rho$ is calibrated to generate the same evolution of household debt as in the other two experiments. This requires gradually 
decreasing $\rho$ from its initial value of 0.0056 to a value of 0.0041 , as shown in panel b of figure 4.3. The resulting dynamics, given by the dashed-dotted lines in figure 4.4, are very similar to those generated by the change in $\theta$ and equally at odds with some of the facts.

We conclude that the four phenomena discussed in the introduction are unlikely to have been generated by looser borrowing constraints and that an increase in credit supply associated with lower barriers to mortgage lending is a much more plausible driver of the housing and credit boom.

4.4. Why house prices started to fall: a potential trigger for the bust. The experiments presented in section 4.3 analyze the consequences of looser collateral constraints in an economy without lending limits, or in which those limits are high enough to be irrelevant for the equilibrium. This subsection shows that the same relaxation of collateral constraints has substantially different effects if lending constraints are in fact present, and eventually become binding. In this scenario, an increase in $\theta$ not only lifts interest rates and the debtto-collateral ratio, but it also depresses house prices. These outcomes are consistent with observations between 2006 and 2008, when the mature phase of the housing boom gave way to the bust. This novel account of the turnaround in the cycle is appealing because it does not rely on a reversal of the forces behind the boom, unlike most of the literature. ${ }^{14}$ However, given its simplicity, the model has no ambition to capture the intricate dynamics of the financial and economic crisis that followed the fall in house prices.

To illustrate the mechanics of a fall in house prices, we modify the experiment of section 4.2 so that the surge in $\bar{L}$ between 2000 and the end of 2005 is followed by an increase in $\theta$ from 0.8 in 2006 to 1.02 at the end of 2008 . Figure 4.5 shows the results of this combined experiment. These simulations are identical to those in figure 4.2 through the end of 2005 . At that date the lending constraint is no longer binding, due to the expansion in $\bar{L}$, and the equilibrium is determined by the collateral constraint, as in figure 3.2. However, starting in 2006 the increase in $\theta$ relaxes the collateral constraint, shifting the kink in the demand for funds to the right, so that the collateral and lending constraint are once again both binding.

When both constraints bind, a marginal loosening of the borrowing constraint (i.e. a higher $\theta$ ) reduces house prices, as in case (iii) of Proposition 1 , since $\bar{L}=\theta p_{t} \bar{h}_{b}$. According

\footnotetext{
${ }^{14}$ For an exception, see Burnside et al. (2013). They present a model model with houses, but no credit, in which the boom sows the seeds of the bust.
} 

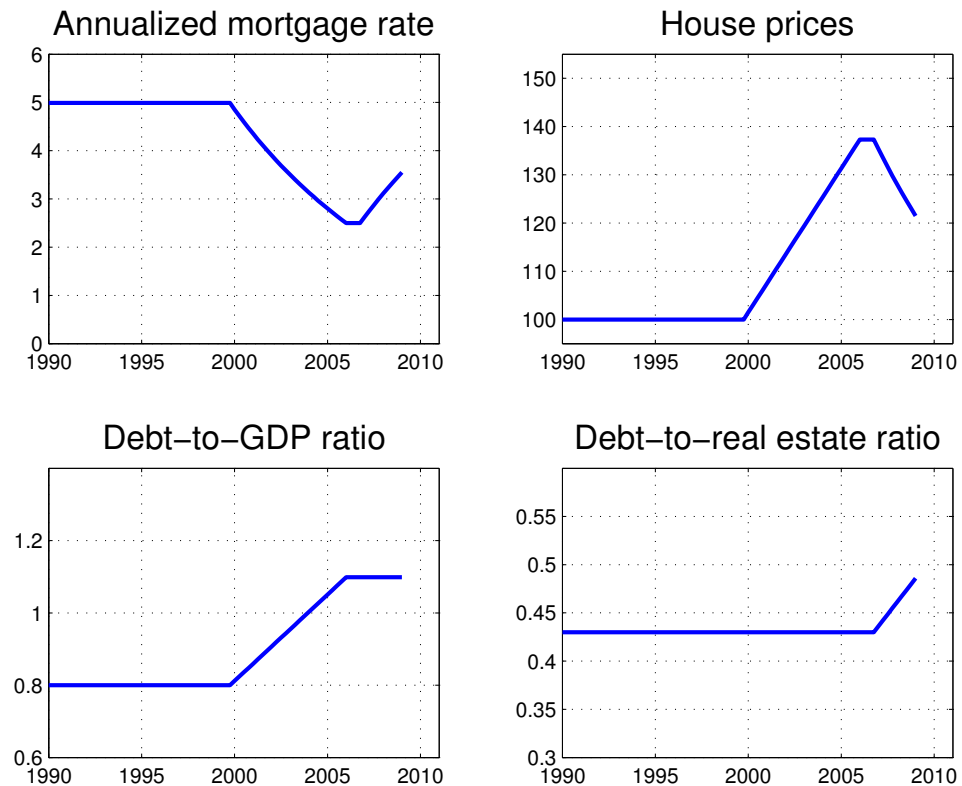

FIgURE 4.5. The response to a loosening of lending constraints (an increase in the lending limit $\bar{L}$ ) followed by a relaxation of collateral constraints (an increase in the maximum loan-to-value ratio $\theta$ ).

to this restriction, equilibrium borrowing cannot exceed the limited amount of available funds. Therefore collateral values must fall when leverage is allowed to rise, so as to leave overall borrowing unchanged at the level dictated by the lending constraint. In other words, a slackening of the borrowing constraint reduces its shadow value $\left(\mu_{t}\right)$ by more when the amount of borrowing is constrained by the supply of funds rather than by their demand, and when credit supply is not very interest-rate elastic. As house prices fall, mortgage rates increase, debt is stable and the debt-to-collateral ratio rises, as shown in figure 4.5. All these outcomes are broadly consistent with the evolution of these variables in the early phase of the housing and credit bust.

In the experiment of this subsection, we increased $\bar{L}$ and $\theta$ sequentially to isolate their relative role in the boom and bust episode. In reality, the relaxation of lending and borrowing constraints is more likely to have proceeded in parallel, since both margins are a manifestation of a broader process of financial liberalization. However, the model's simple insight is that an increase in $\theta$ will trigger a fall in house prices, even in environments 
in which the two constraints are connected, as long as the expansion in credit demand eventually outpaces that in supply.

\section{Concluding Remarks}

An unprecedented boom and bust in house prices and household debt have been among the defining features of the U.S. macroeconomic landscape since the turn of the millennium. Common accounts of this credit cycle, in the economics literature and beyond, have pointed to changes in the tightness of borrowing constraints, and to the consequent shifts in credit demand, as its key driver. In this paper, we argued that the focus of this discussion should shift from constraints on borrowing to obstacles to lending, when it comes to understanding the boom phase of the cycle.

Using a stylized model of borrowing and lending between patient and impatient households, we showed that the progressive erosion of these barriers is consistent with four key empirical facts characterizing the boom: the large increase in house prices and mortgage debt, a stable ratio between mortgages and the value of the real estate that collateralizes them, and the fall in mortgage interest rates. The model's ability to reproduce these facts depends on the interaction between borrowing and lending constraints, and it cannot be reproduced with either of the two constraints in isolation. In fact, the interplay of the two constraints produces rich dynamics of interest rates, debt and house prices, which even hint at a possible trigger of the fall in house prices.

To maximize our model's tractability, and the transparency of its insights, we abstracted from risk entirely. According to Favilukis et al. (2013), this is an important ingredient to understand the evolution of house prices in response to a credit liberalization. Enriching our framework along these lines represents an interesting, if challenging, avenue for future research.

\section{Appendix A. Proof of proposition 1}

To prove part (i) of the proposition, consider first the case in which the lending constraint is binding, but the collateral constraint is not, so that $D_{b, t}=\bar{L}<\theta p_{t} \bar{h}_{b}, \xi_{t}>0$ and $\mu_{t}=0$. With linear utility in consumption, $R_{t}=1 / \beta_{b}$ follows from equation (2.3), and equation

(2.4) implies $p_{t}=\frac{\beta_{b} m r s}{1-\beta_{b}(1-\delta)} \equiv \underline{p}$. For this to be an equilibrium, we must verify that the collateral constraint is not binding, as assumed initially. This requires $\bar{L}<\theta p \bar{h}_{b}$. 
To prove part (ii) of the proposition, consider the opposite case in which the collateral constraint is binding, but the lending constraint is not. It follows that $D_{b, t}=\theta p_{t} \bar{h}_{b}<\bar{L}$, $\xi_{t}=0$ and $\mu_{t}>0$. We can now derive $R_{t}=1 / \beta_{l}$ from equation (2.7), while equation (2.3) implies $\mu_{t}=\beta_{b} / \beta_{l}-1$. Substituting the expression for $\mu_{t}$ into equation (2.4) yields $p_{t}=\frac{\tilde{\beta}(\theta) m r s}{1-\tilde{\beta}(\theta)(1-\delta)} \equiv \bar{p}(\theta)$, where $\tilde{\beta}(\theta) \equiv \frac{\beta_{b} \beta_{l}}{\theta \beta_{b}+(1-\theta) \beta_{l}}$. This is an equilibrium, provided that $\bar{L}>\theta \bar{p}(\theta) \bar{h}_{b}$.

To prove part (iii) of the proposition, we must find the equilibrium in the region of the parameter space in which $\theta p \bar{h}_{b} \leq \bar{L} \leq \theta \bar{p}(\theta) \bar{h}_{b}$. Equations (2.3) and (2.7) together imply that at least one of the two constraints must be binding in this region, but parts (i) and (ii) of the proposition imply that it cannot be that only one of them binds in this region. It follows that both constraints must be binding, implying $D_{b, t}=\bar{L}=\theta p_{t} \bar{h}_{b}$ and $p_{t}=\frac{\bar{L}}{\theta \bar{h}_{b}}$. Substituting the expression for $p_{t}$ into equation (2.4), we can compute $\mu_{t}=\frac{1-\beta_{b}(1-\delta)-m r s \cdot \beta_{b} \theta \bar{h}_{b} / \bar{L}}{\theta}$ and, using (2.3), $R_{t}=\frac{1}{\beta_{b}}\left[1-\frac{1-\beta_{b}(1-\delta)-m r s \cdot \beta_{b} \theta \bar{h}_{b} / \bar{L}}{\theta}\right]$. Finally, $\mu_{t}$ satisfies $\mu_{t} \geq 0$ as long as $\theta \underline{p} \bar{h}_{b} \leq \bar{L} \leq \theta \bar{p}(\theta) \bar{h}_{b}$, which concludes the proof.

\section{Appendix B. A Simple Model with Financial Intermediaries and Capital}

\section{REQUIREMENTS}

This appendix shows that our simple baseline model with a parametric lending limit $\bar{L}$ is equivalent to the limiting case of a more realistic model with financial intermediation. In this model, intermediaries face a capital requirement that their equity be above a certain fraction of their assets, as in He and Krishnamurthy (2013) and Brunnermeier and Sannikov (2014). Intermediaries finance mortgages by collecting savings from the patient households in the form of either debt (i.e. deposits) or equity, where the latter can only be adjusted by paying a convex cost, similar to Jermann and Quadrini (2012). In the limit in which the marginal cost of adjustment tends to infinity, so that equity is fixed in equilibrium, the capital requirement becomes a hard constraint on the funds supplied to the borrowers, exactly as in the baseline model.

Although this case with infinite adjustment costs is extreme, it is qualitatively consistent with the evidence on the stickiness of intermediaries' equity first uncovered by Adrian and Shin (2010b). If the marginal cost of adjusting the intermediaries' capital were not prohibitively large, as assumed here, the resulting supply of funds would be differentiable, 
rather than having a kink, but it would still be upward sloping. This property of the supply of mortgage finance is the key driver of our results.

In the model with intermediaries, competitive "banks" finance mortgages with a mix of equity and deposits collected from the savers. Although the borrowers receive funds from the intermediaries, rather than directly from the savers, their optimization problem is identical to the one in section 2. The lenders, in contrast, maximize the same utility function as in section 2 , but subject to the flow budget constraint

$$
c_{l, t}+p_{t}\left[h_{l, t+1}-(1-\delta) h_{l, t}\right]-D_{l, t}+E_{t} \leq y_{l, t}-R_{t-1}^{D} D_{l, t-1}+R_{t-1}^{E} E_{t-1}
$$

where $-D_{l, t}$ represents "deposits", which pay a gross interest rate $R_{t}^{D}$, and $E_{t}$ represents equity capital, with rate of return $R_{t}^{E}$. These interest rates can differ from the borrowing rate $R_{t}$.

With linear utility in consumption, the first order conditions of the problem of the lenders become

$$
R_{t}^{D}=R_{t}^{E}=\frac{1}{\beta_{l}}
$$

together with the condition $h_{l, t}=\bar{h}_{l}$ following from the maintained assumption that the lenders' demand for houses is rigid.

The competitive financial intermediaries maximize profits

$$
R_{t} D_{b, t}+R_{t}^{D} D_{l, t}-R_{t}^{E}\left[1+f\left(E_{t}\right)\right] E_{t}
$$

subject to the constraint that assets must equal liabilities,

$$
D_{b, t}+D_{l, t}=E_{t}
$$

and to a "capital requirement" that limits lending to a multiple of equity,

$$
D_{b, t} \leq \chi E_{t}
$$

The function $f\left(E_{t}\right)$ represents a convex cost of issuing equity. As in Jermann and Quadrini (2012), this cost is positive, creating a pecking order of liabilities whereby debt is preferred to equity. We parametrize it as

$$
f\left(\frac{E_{t}}{\bar{E}}\right)=\tau\left(\frac{E_{t}}{\bar{E}}\right)^{\gamma}
$$


so that the bank's first order conditions become

$$
\begin{gathered}
R_{t}-R_{t}^{D}=\phi_{t} \\
R_{t}^{E}\left[1+\tau(1+\gamma)\left(\frac{E_{t}}{\bar{E}}\right)^{\gamma}\right]-R_{t}^{D}=\chi \phi_{t},
\end{gathered}
$$

where $\phi_{t}$ is the Lagrange multiplier on the capital requirement.

Combining these two conditions with the fact that $R_{t}^{D}=R_{t}^{E}$, we find that the interest rate on loans is a weighted average of the cost of funding these loans with equity and deposits

$$
R_{t}=\frac{1}{\chi} R_{t}^{D}\left[1+\tau(1+\gamma)\left(\frac{E_{t}}{\bar{E}}\right)^{\gamma}\right]+\frac{\chi-1}{\chi} R_{t}^{D}
$$

In this expression, $1 / \chi$ is the share of bank liabilities held as equity when the capital requirement is binding. Its cost is a markup over the interest rate on deposits $R_{t}^{D}$, which reflects the marginal cost of issuing equity.

Since this marginal cost is everywhere positive, debt is always preferable to equity, making the capital requirement constraint always binding for the financial intermediary. Therefore, we can turn equation (B.7) into the supply of funds by substituting $E_{t}=D_{b, t} / \chi$ to obtain

$$
R_{t}=\frac{1}{\beta_{l}}\left[1+\frac{\tau(1+\gamma)}{\chi}\left(\frac{D_{b, t}}{\chi \bar{E}}\right)^{\gamma}\right]
$$

This supply function is increasing and convex for $\gamma>1$. When $\gamma \rightarrow \infty$, the function exhibits a kink at $D_{b, t}=\chi \bar{E}$, thus establishing the equivalence between this model with intermediation and the simple model with a lending constraint, if we set $\bar{L}=\chi \bar{E}$. This equivalence furthermore provides an interpretation for changes in the lending limit $\bar{L}$, as stemming from changes in the leverage ratio of intermediaries $\chi$, or in their cost of issuing equity.

\section{Appendix C. Solution of the model With home EQuity aCCumulation}

The model used in section 4 to generate the quantitative results differs from that illustrated in section 2 because the collateral constraint includes amortization of the principal. This generalization involves replacing expression (2.1) with (4.1) and (4.3). The optimality 
conditions of the problem of the borrowers therefore become

$$
\begin{gathered}
\left(1-\mu_{t}\right) u^{\prime}\left(c_{b, t}\right)=\beta_{b} R_{t} E_{t} u^{\prime}\left(c_{b, t+1}\right) \\
\left(1-\zeta_{t}\right) u^{\prime}\left(c_{b, t}\right) p_{t}=\beta_{b} v_{b}^{\prime}\left(h_{b, t+1}\right)+\beta_{b}(1-\delta) E_{t}\left[\left(1-\zeta_{t+1}\right) u^{\prime}\left(c_{b, t+1}\right) p_{t+1}\right] \\
\left(\zeta_{t}-\theta \mu_{t}\right) u^{\prime}\left(c_{b, t}\right) p_{t}=\beta_{b} E_{t}\left[(1-\rho) \zeta_{t+1} u^{\prime}\left(c_{b, t+1}\right) p_{t+1}\right] \\
c_{b, t}+p_{t}\left[h_{b, t+1}-(1-\delta) h_{b, t}\right]+R_{t-1} D_{b, t-1}=y_{b, t}+D_{b, t} \\
\mu_{t}\left(D_{b, t}-\theta p_{t} \mathcal{H}_{b, t+1}\right)=0, \quad \mu_{t} \geq 0, \quad D_{b, t} \leq \theta p_{t} \mathcal{H}_{b, t+1}, \\
\mathcal{H}_{b, t+1}=(1-\rho) \mathcal{H}_{b, t}+\left[h_{b, t+1}-(1-\delta) h_{b, t}\right]
\end{gathered}
$$

where $u^{\prime}\left(c_{b, t}\right) \cdot \mu_{t}$ and $u^{\prime}\left(c_{b, t}\right) \cdot p_{t} \cdot \zeta_{t}$ are the Lagrange multipliers on the constraint $D_{b, t} \leq$ $\theta p_{t} \mathcal{H}_{b, t+1}$ and on the evolution of $\mathcal{H}_{b, t+1}$ respectively. The optimality conditions of the problem of the lenders and the market clearing conditions are the same as in the baseline.

To solve this model, first note that

$$
\mathcal{H}_{b, t+1}=\frac{\delta}{\rho} \bar{h}_{b}
$$

Suppose now that the lending constraint is binding and the collateral constraint is not, so that $D_{b, t}=\bar{L}<\theta p_{t} \frac{\delta}{\rho} \bar{h}_{b}, \xi_{t}>0$ and $\mu_{t}=0$. With linear utility in consumption, $R_{t}=1 / \beta_{b}$ follows from equation (C.1), and equations (C.2) and (C.3) imply $p_{t}=\frac{\beta_{b} m r s}{1-\beta_{b}(1-\delta)} \equiv \underline{p}$. For this to be an equilibrium, the collateral constraint must actually not be binding, as assumed above. This requires $\bar{L}<\theta \underline{p} \frac{\delta}{\rho} \bar{h}_{b}$.

Suppose now to be in the opposite situation in which the collateral constraint is binding, while the lending constraint is not. It follows that $D_{b, t}=\theta p_{t} \frac{\delta}{\rho} \bar{h}_{b}<\bar{L}, \xi_{t}=0$ and $\mu_{t}>0$. We can now derive $R_{t}=1 / \beta_{l}$ from equation (2.7), while equation (C.1) implies $\mu_{t}=\beta_{b} / \beta_{l}-1$. Substituting the expression for $\mu_{t}$ into equation (C.3) and combining it with (C.2) yields

$$
p_{t}=\frac{\beta_{b} m r s}{1-\beta_{b}(1-\delta)} \cdot \frac{1-\beta_{b}(1-\rho)}{1-\beta_{b}(1-\rho)-\theta\left(1-\beta_{b} / \beta_{l}\right)} \equiv \bar{p}(\theta, \rho)>\underline{p} .
$$

This is an equilibrium, provided that $\bar{L}>\theta \bar{p}(\theta) \frac{\delta}{\rho} \bar{h}_{b}$. 
Finally, we must find the equilibrium of the model in the region of the parameter space in which $\theta \underline{p} \frac{\delta}{\rho} \bar{h}_{b} \leq \bar{L} \leq \theta \bar{p}(\theta) \frac{\delta}{\rho} \bar{h}_{b}$. Combining equations (C.1) and (2.7) implies that at least one of the two constraints must be binding, and the results above show that the value of the parameters in this region is inconsistent with only one of them being binding. It follows that both constraints must bind at the same time, implying $D_{b, t}=\bar{L}=\theta p_{t} \frac{\delta}{\rho} \bar{h}_{b}$ and $p_{t}=\frac{\rho}{\delta} \frac{\bar{L}}{\theta \bar{h}_{b}}$. Substituting the expression for $p_{t}$ into equations (C.2) and (C.3), we can compute the equilibrium value of $\mu_{t}=\frac{1-\beta_{b}(1-\delta)-m r s \cdot \beta_{b} \delta \theta \bar{h}_{b} /(\rho \bar{L})}{\theta} \cdot \frac{1-\beta_{b}(1-\rho)}{1-\beta_{b}(1-\delta)}$, and verify that it is positive if $\theta \underline{p} \frac{\delta}{\rho} \bar{h}_{b} \leq \bar{L} \leq \theta \bar{p}(\theta) \frac{\delta}{\rho} \bar{h}_{b}$. We can then obtain $R_{t}=$ $\frac{1}{\beta_{b}}\left[1-\frac{1-\beta_{b}(1-\delta)-m r s \cdot \beta_{b} \delta \theta \bar{h}_{b} /(\rho \bar{L})}{\theta} \cdot \frac{1-\beta_{b}(1-\rho)}{1-\beta_{b}(1-\delta)}\right]$ using (C.1).

These results can be summarized in the following proposition.

Proposition 2. In the model of section 4 there exist two threshold house prices, $\underline{p} \equiv$ $\frac{\beta_{b} \cdot m r s}{1-\beta_{b}(1-\delta)}$ and $\bar{p}(\theta, \rho) \equiv \frac{\beta_{b} \cdot m r s}{1-\beta_{b}(1-\delta)} \cdot \frac{1-\beta_{b}(1-\rho)}{1-\beta_{b}(1-\rho)-\theta\left(1-\beta_{b} / \beta_{l}\right)}$, such that:

(i) if $\bar{L}<\theta \underline{p} \underline{\delta} \bar{h}_{b}$, the lending constraint is binding and

$$
p_{t}=\underline{p}, \quad D_{b, t}=\bar{L} \quad \text { and } \quad R_{t}=\frac{1}{\beta_{b}} ;
$$

(ii) if $\bar{L}>\theta \bar{p}(\theta, \rho) \frac{\delta}{\rho} \bar{h}_{b}$, the borrowing constraint is binding and

$$
p_{t}=\bar{p}(\theta, \rho), \quad D_{b, t}=\theta \bar{p}(\theta, \rho) \frac{\delta}{\rho} \bar{h}_{b} \quad \text { and } \quad R_{t}=\frac{1}{\beta_{l}}
$$

(iii) if $\theta \underline{p} \frac{\delta}{\rho} \bar{h}_{b} \leq \bar{L} \leq \theta \bar{p}(\theta, \rho) \frac{\delta}{\rho} \bar{h}_{b}$, both constraints are binding and

$$
\begin{gathered}
p_{t}=\frac{\rho}{\delta} \frac{\bar{L}}{\theta \bar{h}_{b}}, \quad D_{b, t}=\bar{L} \quad \text { and } \\
R_{t}=\frac{1}{\beta_{b}}\left[1-\frac{1-\beta_{b}(1-\delta)-m r s \cdot \beta_{b} \delta \theta \bar{h}_{b} /(\rho \bar{L})}{\theta} \cdot \frac{1-\beta_{b}(1-\rho)}{1-\beta_{b}(1-\delta)}\right] ;
\end{gathered}
$$

where $m r s \equiv v^{\prime}\left(\bar{h}-\bar{h}_{l}\right)$ and $\bar{p}(\theta) \geq \underline{p}$ for every $0 \leq \theta \leq 1$.

\section{REFERENCES}

Acharya, V. V. And M. P. Richardson (2009): "Causes of the Financial Crisis," Critical Review, 21, 195-210.

Acharya, V. V., P. Schnabl, And G. Suarez (2013): "Securitization without risk transfer," Journal of Financial Economics, 107, 515-536. 
Adam, K., P. Kuang, And A. Marcet (2012): "House Price Booms and the Current Account," NBER Macroeconomics Annual, 26, 77 - 122.

Adrian, T. AND N. Boyarchenko (2012): "Intermediary leverage cycles and financial stability," Staff Reports 567, Federal Reserve Bank of New York.

- (2013): "Intermediary balance sheets," Staff Reports 651, Federal Reserve Bank of New York.

Adrian, T. And H. S. Shin (2008): "Financial intermediary leverage and value at risk," Staff Reports 338, Federal Reserve Bank of New York.

_ (2010a): "Financial Intermediaries and Monetary Economics," in Handbook of Monetary Economics, ed. by B. M. Friedman and M. Woodford, Elsevier, vol. 3 of Handbook of Monetary Economics, chap. 12, 601-650.

- (2010b): "Liquidity and leverage," Journal of Financial Intermediation, 19, 418-437. (2014): "Procyclical Leverage and Value-at-Risk," Review of Financial Studies, 27, 373-403.

Ambrose, B. W. And T. G. Thibodeau (2004): "Have the GSE affordable housing goals increased the supply of mortgage credit?" Regional Science and Urban Economics, 34, $263-273$.

BAKer, S. R. (2014): "Debt and the Consumption Response to Household Income Shocks," Mimeo, Stanford University.

Bernanke, B. S., C. Bertaut, L. P. Demarco, and S. Kamin (2011): "International capital flows and the returns to safe assets in the United States, 2003-2007," International Finance Discussion Papers 1014, Board of Governors of the Federal Reserve System (U.S.).

Bianchi, J., E. Boz, And E. G. Mendoza (2012): "Macroprudential Policy in a Fisherian Model of Financial Innovation," IMF Economic Review, 60, 223-269.

Bianchi, J. And E. G. Mendoza (2012): "Overborrowing, Financial Crises and 'Macroprudential' Policy," Mimeo, University of Wisconsin.

_ (2013): "Optimal Time-Consistent Macroprudential Policy," NBER Working Papers 19704, National Bureau of Economic Research, Inc.

Bigio, S. (2013): "Financial Risk Capacity," Mimeo, Columbia University.

Boz, E. And E. G. Mendoza (2014): "Financial Innovation, the Discovery of Risk, and the U.S. Credit Crisis," Journal of Monetary Economics, 69, 1-22, forthcoming. 
Brunnermeier, M. K. (2009): "Deciphering the Liquidity and Credit Crunch 2007-2008," Journal of Economic Perspectives, 23, 77-100.

Brunnermeier, M. K. And Y. SAnnikov (2014): "A Macroeconomic Model with a Financial Sector," American Economic Review, forthcoming.

Burnside, C., M. Eichenbaum, and S. Rebelo (2013): "Understanding Booms and Busts in Housing Markets," Mimeo, Northwestern University.

Campbell, J. R. And Z. Hercowitz (2009a): "Liquidity constraints of the middle class," Working Paper Series WP-09-20, Federal Reserve Bank of Chicago.

- (2009b): "Welfare implications of the transition to high household debt," Journal of Monetary Economics, 56, 1-16.

Carroll, C. D., J. Slacalek, and K. Tokuoka (2013): "The Distribution of Wealth and the Marginal Propensity to Consume," Johns Hopkins University, mimeo.

Charles, K. K., E. Hurst, And M. J. Notowidigdo (2014a): "Housing Booms, Labor Market Outcomes, and Educational Attainment," .

(2014b): "Masking and Aggregate Employment Changes: Housing Booms and Manufacturing Declines During the 2000s," .

Christiano, L. J. And D. Ikeda (2013): "Leverage Restrictions in a Business Cycle Model," NBER Working Papers 18688, National Bureau of Economic Research, Inc.

Dewachter, H. And R. Wouters (2012): "Endogenous risk in a DSGE model with capital-constrained financial intermediaries," Working Paper Research 235, National Bank of Belgium.

Di Maggio, M. And A. Kermani (2014): "Credit-Induced Boom and Bust," Mimeo, Columbia University.

Di Maggio, M., A. Kermani, and R. Ramcharan (2014): "Monetary Policy PassThrough: Household Consumption and Voluntary Deleveraging," Mimeo, Columbia Business School.

Duca, J. V., J. Muellbauer, And A. Murphy (2011): "House Prices and Credit Constraints: Making Sense of the US Experience," Economic Journal, 121, 533-551.

Eggertsson, G. B. and P. Krugman (2012): "Debt, Deleveraging, and the Liquidity Trap: A Fisher-Minsky-Koo Approach," The Quarterly Journal of Economics, 127, 14691513. 
FArhi, E. AND I. Werning (2013): "A Theory of Macroprudential Policies in the Presence of Nominal Rigidities," Mimeo, Harvard University.

Favara, G. And J. Imbs (2012): "Credit Supply and the Price of Housing," Mimeo, Boad of Governors of the Federal Reserve System.

Favilukis, J., S. C. Ludvigson, And S. V. Nieuwerburgh (2013): "The Macroecononomic Effects of Housing Wealth, Housing Finance, and Limited Risk Sharing in General Equilibrium," New York University, mimeo.

Fostel, A. And J. Geanakoplos (2012): "Tranching, CDS, and Asset Prices: How Financial Innovation Can Cause Bubbles and Crashes," American Economic Journal: Macroeconomics, 4, 190-225.

Garriga, C., R. E. Manuelli, and A. Peralta-Alva (2012): "A model of price swings in the housing market," Working Papers 2012-022, Federal Reserve Bank of St. Louis.

Geanakoplos, J. (2010): "The Leverage Cycle," NBER Macroeconomics Annual, 24, pp. $1-66$.

Gerali, A., S. Neri, L. Sessa, And F. M. Signoretti (2010): "Credit and Banking in a DSGE Model of the Euro Area," Journal of Money, Credit and Banking, 42, 107-141.

Gerardi, K. S., H. S. Rosen, And P. S. Willen (2010): "The Impact of Deregulation and Financial Innovation on Consumers: The Case of the Mortgage Market," Journal of Finance, 65, 333-360.

Gertler, M. AND P. Karadi (2011): "A model of unconventional monetary policy," Journal of Monetary Economics, 58, 17-34.

Gertler, M. And N. Kiyotaki (2010): "Financial Intermediation and Credit Policy in Business Cycle Analysis," in Handbook of Monetary Economics, ed. by B. M. Friedman and M. Woodford, Elsevier, vol. 3 of Handbook of Monetary Economics, chap. 11, 547599.

Gertler, M., N. Kiyotaki, And A. Queralto (2012): "Financial crises, bank risk exposure and government financial policy," Journal of Monetary Economics, 59, S17S34.

Guerrieri, V. And G. Lorenzoni (2012): "Credit Crises, Precautionary Savings, and the Liquidity Trap," University of Chicago, mimeo.

Hall, R. E. (2011): "The Long Slump," American Economic Review, 101, 431-69. 
_ (2012): "Quantifying the Forces Leading to the Collapse of GDP after the Financial Crisis," Mimeo, Stanford University.

He, Z. And A. Krishnamurthy (2013): "Intermediary Asset Pricing," American Economic Review, 103, 732-770.

Holmstrom, B. And J. Tirole (1997): "Financial Intermediation, Loanable Funds, and the Real Sector," The Quarterly Journal of Economics, 112, 663-91.

Huo, Z. And J.-V. Rios-Rull (2014): "Financial Frictions, Asset Prices, and the Great Recession," Working Paper, Federal Reserve Bank of Minneapolis.

Iacoviello, M. (2005): "House Prices, Borrowing Constraints, and Monetary Policy in the Business Cycle," American Economic Review, 95, 739-764.

_ (2014): "Financial Business Cycles," Mimeo, Board of Governors of the Federal Reserve System.

IACOviello, M. AND S. Neri (2010): "Housing Market Spillovers: Evidence from an Estimated DSGE Model," American Economic Journal: Macroeconomics, 2, 125-64.

Iacoviello, M. And M. Pavan (2013): "Housing and debt over the life cycle and over the business cycle," Journal of Monetary Economics, 60, 221-238.

Jermann, U. And V. QUAdRini (2012): "Macroeconomic Effects of Financial Shocks," American Economic Review, 102, 238-71.

Justiniano, A., G. E. Primiceri, And A. Tambalotti (2014a): "Household Leveraging and Deleveraging," Northwestern University, mimeo.

- (2014b): "The Effects of the Saving and Banking Glut on the U.S. Economy," Journal of International Economics, 92, Supplement 1, S52-S67.

Kaplan, G. And G. Violante (2014): "A Model of the Consumption Response to Fiscal Stimulus Payments," Econometrica.

Kaplan, G., G. Violante, And J. Weidner (2014): "The Wealthy Hand-to-Mouth," Brookings Papers on Economic Activity.

Kermani, A. (2012): "Cheap Credit, Collateral and the Boom-Bust Cycle," Mimeo, University of California.

Kiyotaki, N., A. Michaelides, and K. Nikolov (2011): "Winners and Losers in Housing Markets," Journal of Money, Credit and Banking, 43, 255-296.

Kiyotaki, N. And J. Moore (1997): "Credit Cycles," Journal of Political Economy, 105, 211-48. 
KorineK, A. And A. Simsek (2014): "Liquidity Trap and Excessive Leverage," Johns Hopkins University, mimeo.

Krusell, P. And A. A. Smith (1998): "Income and Wealth Heterogeneity in the Macroeconomy," Journal of Political Economy, 106, 867-896.

Lambertini, L., C. Mendicino, And M. T. Punzi (2013): "Leaning against boomĐbust cycles in credit and housing prices," Journal of Economic Dynamics and Control, 37, $1500-1522$.

Landvoigt, T. (2014): "Aggregate Consequences of the Rise in Securitized Mortgage Debt," .

Landvoigt, T., M. Piazzesi, and M. Schneider (2013): "The Housing Market(s) of San Diego," Stanford University, mimeo.

Levitin, A. And S. Wachter (2012): "Explaining the Housing Bubble," The Georgetown Law Journal, 100, 1177-1258.

Loutskina, E. (2011): "The role of securitization in bank liquidity and funding management," Journal of Financial Economics, 100, 663-684.

Loutskina, E. And P. E. Strahan (2009): "Securitization and the Declining Impact of Bank Finance on Loan Supply: Evidence from Mortgage Acceptance Rates," Journal of Finance, 64, 861-889.

Mendicino, C. (2012): "Collateral Requirements: Macroeconomic Fluctuations and Macro-Prudential Policy," Working Papers w201211, Banco de Portugal, Economics and Research Department.

Mian, A., K. Rao, And A. Sufi (2013): "Household Balance Sheets, Consumption, and the Economic Slump," Quarterly Journal of Economics, 128(4), 1687-1726.

Mian, A. And A. Sufi (2009): "The Consequences of Mortgage Credit Expansion: Evidence from the U.S. Mortgage Default Crisis," The Quarterly Journal of Economics, 124, 1449-1496.

_ (2010): "Household Leverage and the Recession of 2007Đ09," IMF Economic Review, $58,74-117$.

_ (2011): "House Prices, Home Equity-Based Borrowing, and the US Household Leverage Crisis," American Economic Review, 101, 2132-56.

_ (2014a): "House Price Gains and U.S. Household Spending from 2002 to 2006," Mimeo, Princeton University. 
(2014b): "What Explains the 2007-2009 Drop in Employment?" Mimeo, Princeton University.

Midrigan, V. And T. Philippon (2011): "Household Leverage and the Recession," New York University, mimeo.

Nadauld, T. And S. Sherlund (2009): "The Role of the Securitization Process in the Expansion of Subprime Credit," Board of Governors of the Federal Reserve Working Paper 2009-28.

PAlmer, C. (2014): "Why Did So Many Subprime Borrowers Default During the Crisis: Loose Credit or Plummeting Prices?" Mimeo, MIT.

Simsek, A. (2013): "Belief Disagreements and Collateral Constraints," Econometrica, 81, $1-53$.

Federal Reserve Bank of Chicago

E-mail address: ajustiniano@frbchi.org

Northwestern University, CEPR, And NBER

E-mail address: g-primiceri@northwestern.edu

Federal Reserve Bank of New York

E-mail address: a.tambalotti@gmail.com 